\title{
Los proyectos de nueva construcción del Pan- teón Real de San Isidoro de León durante la Monarquía de los Austria
}

\author{
Maㅡoo Campos Sánchez-Bordona \\ Universidad de León
}

\begin{abstract}
RESUMEN. El trabajo analiza los dos intentos de traslado y de nueva construcción del panteón real románico de San Isidoro de León que se desarrollaron durante los reinados de Felipe II y de Carlos II. El primero se proyectó bajo esquemas clasicistas y, el segundo, conforme al ornato barroco, pero en ambos casos se tuvo como referente los esquemas artísticos, litúrgicos y funerarios de El Escorial y su interés político para la Monarquía Hispánica.

Palabras clave: Panteón real, San Isidoro de León, El Escorial, Felipe II, Juan de Herrera, Juan del Ribero Rada, Baltasar Gutiérrez, siglos XVI, siglo XVII, León.

ABSTRACT. This investigation analyzes the two attempts of movement and new construction of the Royal Romanesque Pantheon of San Isidoro of León, which were developed during the reign of Felipe II and Carlos II. The first one was projected under classical characteristics, and the second one, following the baroque ornamentation. But in both cases, the artistic, liturgical and funerary aspects of El Escorial, were taken as reference models, as well as its interest for the Hispanic Monarchy for politics.

Key Words: Panteón real, San Isidoro de León, El Escorial, Felipe II, Juan de Herrera, Juan del Ribero Rada, Baltasar Gutiérrez, XVI century, XVII century, León.
\end{abstract}

Suya y su hechura es la admirable y divina obra de San Lorenzo de El Escorial, digna funda perpetua de los gloriosos y reales cuerpos de los reyes de España, nueva octava maravilla. (L. Zapata, Miscelánea, Memorial Histórico Español, Madrid,1859 XI.p. 358).

La concepción de El Escorial como recinto funerario de la Monarquía hispana está muy clara desde el principio de su fundación por el rey Felipe II. Así lo refiere en su obra Fray José de Sigüenza:

..y con ello propuso y cerró del todo en su pensamiento que el templo que tenía determinado levantar a honra de San Lorenzo fuese un monasterio de la Orden de San Jerónimo, que juntamente fuese sepultura digna de tal Emperador y padre y una emperatriz tal como doña Isabel, su madre, y que después también lo fuese suya, de sus carísimas mujeres e hijos ${ }^{1}$

El padre Sigüenza justifica estas palabras haciendo referencia a la carta fundacional del monasterio, otorgada por el mo-

\footnotetext{
${ }^{1}$ Fr. José DE SIGÜENZA, La fundación del monasterio de El Escorial, Ed. Turner, Madrid, 1988, p. 11
} 
narca el 22 de abril de 1567, en la que, entre otras cosas, el rey Prudente expresa:

....para que así mismo se ruegue e interceda a Dios por nos e por los Reyes nuestros antecesores y sucesores, e por el bien de nuestras ánimas e la conservación de nuestro estado real, teniendo así mismo fin e consideración a que el Emperador y Rey, mi señor y padre, ...... el de la Emperatriz y Reina, mi señora y madre, habían de ser puestos y colocados siendo cosa justa y decente que sus cuerpos sean muy honorablemente sepultados, e por sus ánimas se hagan e digan continuas oraciones, conmemoraciones $e$ memorias $^{2}$.

El tema se relaciona con la propia configuración política de la Monarquía Hispánica llevada a cabo por Felipe II, acerca de la cual desarrolla un nuevo concepto, en donde sobresalen aspectos como el compromiso con la confesión católica, la identificación dinástica con los viejos reinos hispanos, así como el carácter autoritario, el control y la centralización de la corte y de los reinos, aspectos que serán legados a sus herederos ${ }^{3}$.

En este sentido, El Escorial tiene mucho que ver con la idea de dinastía en cuanto soporte esencial del orden monárquico de sucesión y como fuente de legitimación de la Casa de Austria y, sobre todo, con el impulso dado por el rey Prudente al culto a las reliquias. ${ }^{4}$. Ambas cuestiones le conducirán a la veneración de los antepasados reales como auténticas reliquias $\mathrm{y}$, consi-

\footnotetext{
${ }^{2}$ Fr. José De SigÜENZA, La fundación del monasterio de .., p. 12; J. ZARCO CUEVAS, Documentos para la Historia del Monasterio de San Lorenzo de El Real de El Escorial II. Testam,ento y codicilos de Felipe II.., Madrid, 1917.

3 J. MARTíneZ Millán “ Monarquía hispánica de Felipe II" en Felipe II y el arte de su tiempo, Madrid, 1998, pp.13-18

4 J. M del EsTAL, "Felipe II y el culto a los santos", en Felipe II y su época, Actas del Simposio, (I), Estudios Superiores del Escorial, San Lorenzo del Escorial, (Madrid), 1998, en especial el apartado "Culto de Felipe II a los santos y a las reliquias", pp. 457-501.
}

guientemente, determinarán la necesidad de levantar una digna morada fúnebre, concebida como panteón para los propios ascendientes aúlicos (paternos y maternos), contemplados como piezas esenciales en la fundamentación dinástica de su autoridad regia.

Como clara demostración del carácter funerario y político del recinto escurialense, en 1573 dieron comienzo las ceremonias de traslado de algunos cuerpos de sus ascendientes regios más inmediatos desde los diversos lugares de la Península, en los que hasta entonces estaban enterrados, hasta el "panteón de prestado" ubicado bajo el presbiterio de la iglesia vieja de El Escorial. Si en 1573 llegaron los restos de Isabel de Valois y del príncipe Carlos, a partir de 1574 lo hicieron los de Carlos V, la emperatriz Isabel de Portugal, la reina doña Juana, doña María de Portugal (primera esposa de Felipe II), Leonor de Francia, María de Hungría y el infante don Fernando. En 1579 fueron depositados los de don Juan de Austria y en 1580 los de Ana de Austria $^{5}$. Los reales féretros, de factura muy sencilla, se dispusieron en manera seriada y ordenada, en forma de $\mathrm{U}$, bajo el presbiterio de la primitiva basílica de San Lorenzo, según se contempla en el dibujo procedente de la Memorias de Fray Juan de San Gerónimo, conservado en la Biblioteca del Real Monasterio de San Lorenzo ${ }^{6}$. Allí permanecieron

\footnotetext{
${ }^{5}$ La documentación sobre estos traslados se guarda en AGS, CRS, leg, 268, f. 188. Citado por F. CHECA, Felipe II mecenas de las artes, Madrid, 1992, p. 485. También se hacen referencia a estos hechos en A. BUSTAMANTE, "Túmulos reales del Escorial, en Felipe II y el arte de su tiempo, Madrid, 1998, pp. 55-78.

${ }^{6}$ Se trata de dos dibujos, uno con la vista del "Panteón de prestado" de la Iglesia Vieja del monasterio y otro con la planta de dicho espacio y colocación de los féretros debajo del altar de esa vieja iglesia basilical que se encuentran en la Memorias de Fray Juan de San Gerónimo, Biblioteca del Real Monasterio de San Lorenzo de El Escorial, Patrimonio Nacional, Ms. K-17. Ambos dibujos han sido publicados en A. BUSTAMANTE, "El Panteón de El Escorial. Papeletas para su histo-
} 
hasta la definitiva conclusión del panteón escurialense, ubicado bajo la capilla mayor del templo. Este conjunto, trazado inicialmente en 1562 por Juan Bautista de Toledo, fue rectificado en 1572 por Juan de Herrera, y modificado varios años después según los diseños de Crescenci y Gómez de Mora, siendo terminado por Alonso Carbonell en el reinado de Felipe IV $^{7}$.

Paralelamente, en ese amplio margen de tiempo, Juan de Herrera, de acuerdo a solicitud del rey formulada en 1572, realiza nuevas trazas para disponer los cenotafios reales, con las esculturas de la familia de Carlos V y de Felipe II, encastrados en las paredes laterales de la cabecera de la iglesia del monasterio de San Lorenzo. Las trazas del presbiterio de la basílica, fechadas 1573, ofrecen ya esta ubicación y las características generales de un proyecto que se iría concretando en años sucesivos, en donde prima la idea de la unión de la realeza con la divinidad, conforme a la imagen del rey que el monarca hispano quiso trasmitir y que quedó perfectamente plasmada en las estatuas en bronce realizadas por los Leoni unos años más tarde ${ }^{8}$. Aunque a primera vista la disposición de estos cenotafios con las imágenes orantes de los reyes traigan a la memoria algunos ejemplos parietales italianos del siglo XVI y den la sensación de

ria" Anuario del Departamento de Historia y Teoría del Arte, Universidad Autónoma de Madrid, vol, IV, 1992, pp.161-215; A. BuSTAMANTE, “Las trazas de la Biblioteca del Palacio Real de Madrid. Felipe II y sus arquitectos" en Las trazas de Juan de Herrera y sus seguidores, Patrimonio Nacional, Madrid-Santander, 2001, pp. , 289-336.

${ }^{7}$ A. Bustamante, "El Panteón de El Escorial. Papeletas..." , pp.161-215.

${ }^{8}$ A. BUSTAMANTE, "Túmulos reales...", p. 76; Idem, "Las estatuas de bronce del Escorial. Datos para su historia (I)", Anuario del Departamento de Historia y Teoría del Arte de la Universidad Autónoma de Madrid, V, 1993, pp. 41-57; Idem, "Las estatuas en bronce del Escorial. Datos para su historia (II)", Anuario del Departamento de Historia y Teoría del Arte de la UAM, VI, 1994, pp. 159-177 alejarse de la tradición hispana del sepulcro cama con yacente, dispuesto en la parte central del espacio funerario, sin embargo, están presentes los ecos de las Huelgas Reales de Burgos y de otros tantos ejemplos castellanos del siglo XV. Es posible que en dicha disposición primara la intencionalidad de visualizar mejor la concepción de la capilla mayor, en consonancia con los esquemas espaciales contrarreformistas $y$ clasicistas, sin renunciar a disposición de los "entierros" en el mismo plano del retablo, de forma que las figuras regias, cual reliquias o cuerpos santos, expresasen la unión de lo aúlico y sagrado ${ }^{9}$.

El magno proyecto funerario del Escorial no fue un hecho aislado en la política de la nueva Monarquía Hispánica. Si el panteón escurialense era el refrendo de su concepción del poder y del culto a las reliquias de los antepasados, así como de un acercamiento a la idea imperial romana, también otros panteones reales dispersos por diferentes lugares de la península fueron motivo de atención por parte de Felipe II, dentro de un proyecto global de legitimación dinástica y de reforzamiento de la imagen del rey, que vuelve la mirada a la antigua monarquía de los viejos reinos peninsulares de León y Castilla e, incluso, de Portugal, (como se materializó en el proyecto de San Vicente da Fora, en Lisboa). Tal actitud enlazaba, además, con el imperante deseo del Rey Prudente por el control de todo el aparato eclesiástico, en especial el vinculado a la Corona, como eran las iglesias de patronato, el gobierno episcopal, los templos, abadías, monasterios, colegiatas y prioratos dependientes de la institución monárquica y panteones reales ${ }^{10}$.

\footnotetext{
9 A. BuSTAMANTE, “Túmulos reales..", p- 76.

${ }^{10}$ Sobre el afán del control eclesiástico por parte de Felipe II remitimos al trabajo de J. GARCIA ORO y M. J. PORTEla Silva, Felipe II y el Patronato real en Castilla, Madrid, 2000
} 
Por lo que respecta a la tutela de las capillas y panteones reales, el monarca español la orientó en la recomposición y ornato de tales recintos sacros, mostrando siempre una clara preocupación por conferir a estos espacios funerarios la solemnidad y decoro que correspondía a su real patrocinio, disponiendo en muchas ocasiones su reforma o mejora arquitectónica. Las décadas de los años setenta y ochenta del siglo XVI nos han legado multitud de ejemplos de esa política de patronato regio, en donde adquiere un verdadero protagonismo la ubicación de los sepulcros reales, e incluso su traslado a otros nuevos espacios sacros levantados para tal fin.

No en vano, coincidiendo con el traslado de los primeros cuerpos reales al Panteón de prestado escurialense, se producen diferentes intervenciones regias a favor del patronato real en templos asturianos, granadinos, toledanos, sevillanos, matritenses, y castellanos ${ }^{11}$. Fue por esas mismas fechas (1575) cuando, según relata el cronista Estebán de Garibay, Felipe II se interesó y visitó las tumbas de los reyes godos Flavio, Recesvinto y Wamba, en Santa Leocadia de Toledo, quizás, y según la opinión de Cristóbal de Bernal, testigo de los hechos, con el ánimo de trasladar al Escorial algunos de estos cuerpos ${ }^{12}$. En esa misma jornada tole-

\footnotetext{
${ }^{11}$ El conjunto de los recintos funerarios de los reyes medievales hispanos se analiza en I. BANGO TORVISO "Espacio para los enterramientos privilegiados en la arquitectura medieval española", Anuario del Departamento de Historia y Teoría del Arte, Universidad Autónoma de Madrid, vol, IV, 1992, pp. 93-132.

${ }^{12}$ La descripción de la visita de Felipe II a Toledo y en concreto a la cripta de Santa Leocadia aparece reflejada por el cronista real Esteban de Garibay y Zamalloa, en su manuscrito Los siete libros de la Progenie y parentela de los hijos de Esteba de Garibay, conocido como "Memorias de Esteban de Garibay," Edit. Por J. A. ACHÓN INSAUSTI, Mondragón, 2002. Por lo que respecta a la opinión de Cristóbal Bernal sobre los deseos del rey de trasladar los cuerpos de Recesvinto y Wamba al Escorial, se anota en una carta que éste dirige a Don Diego de Guzmán, embajador en Venecia, fechada en
}

dana el rey también visitó la catedral primada y San Juan de los Reyes, otros dos conjuntos sacros que reunían recintos funerarios relacionados con antepasados re$\operatorname{gios}^{13}$. En dicho templo catedralicio el monarca puso especial cuidado en reformar la vida y el adecuado funcionamiento de la de la capilla de la reina Catalina o capilla de Santa Cruz ${ }^{14}$ y de la Capilla de los Reyes Nuevos ${ }^{15}$, interviniendo en la provisión de capellanías, en el control del tesoro y de las arcas e inspeccionando el cumplimiento de las obligaciones de ambas, para lo cual se dispuso nombrar visitadores que comuniquen al rey: ...Si el capellán mayor y capellanes della han servido y sirven sus capellanías por

Toledo en mayo de 1575 conservada en AGS, Secretaría de Estado, leg. 1515, no 94, publicada por L. CERVERA VERA, Colección de documentos para la Historia del Arte en España. Documentos biográficos de Juan de Herrera, I, Madrid-Zaragoza, 1981-87, pp. 200. También se hace referencia a estos datos en M. A. ARAMBURU-ZABALA, C. LOSADA Y A. CAGIGAS, Biografía de Juan de Herrera, Santander, 2003, p. 252.

${ }^{13}$ En la catedral de Toledo se había proyectado también como posible panteón real, de hecho allí estaban los sepulcros de Alfonso VII, el infante don Pedro, Sancho III, Sancho IV, Enrique II, Catalina de Lancanster, doña Juana Manuel y Enrique III.

${ }^{14}$ La capilla de Santa Cruz fue fundada por Sancho IV en 1289, y a ella se trasladaron los cuerpos de Alfonso VII, Sancho III y, tras su muerte, en 1295, Sancho IV. Este espacio fue modificado en el siglo XV por el cardenal Cisneros, cuando se amplió el presbiterio, depositando algunos cuerpos en la capilla del Espíritu Santo. Sobre este recinto funerario vid: V. GARCÍA BEY, " La capilla del rey Sancho el Bravo y los cenotafios de la catedral de Toledo" Boletín de la Real Academia de Bellas Artes y Ciencias Históricas de Toledo, 1922, pp. 129-148; Ricardo del ARCO, Sepulcros de la Casa Real de Castilla, Madrid, 1954, p. 101.

${ }^{15}$ Dicha capilla fue fundada por Enrique II a modo de panteón real. En ella se depositaron varios cuerpos de la dinastía de los Trastámara. Allí descansan Enrique II (1374), Catalina de Lancanster (1418), doña Juana Manuel y Enrique III y Juan I. Fue reformada en el siglo XVI bajo la prelatura del arzobispo Fonseca. Sobre este espacio remitimos al estudio de T. PÉREZ HigUERA, “Los sepulcros de Reyes Nuevos en la catedral de Toledo", Tekné, 1985, pp. 131-139; R. DíEZ DEL CORRAL, Arquitectura y mecenazgo. La imagen de Toledo en el renacimiento, Madrid, 1987, pp. 86-91. 
sus personas, como son obligados, y si dizen las misas y aniversarios y los otros oficios y memorias que deven hazer por las animas de los Reyes nuestros progenitores que la fundaron y dotaron $^{16}$. Información que trataba de aportar al monarca los datos necesarios para su posible utilización en San Lorenzo de El Escorial $^{17}$.

También en Granada, su Capilla Real fue motivo de especial atención por parte del Felipe II con el ánimo de que dicho mausoleo brillara con el esplendor que correspondía a lo cuerpos allí depositados. En la década de los años setenta y ochenta de la centuria se llegó incluso a plantear la posibilidad de incorporar, o trasladar, el recinto funerario, con los cenotafios de los Reyes Católicos y de Juana y Felipe el Hermoso, al interior del templo catedralicio granadino, idea finalmente desechada y

-

${ }^{16}$ AHN, Consejos, lib. 2, f. 74v-76v, Felipe II comisiona al licenciado Rades de Andrade para visitar la capilla de los Reyes Nuevos de Toledo. El documento está fechado en El Pardo el 11 de julio de 1579. En la misma línea se pronuncia el monarca años después, en 1587 , a la hora de confirmar las nuevas constituciones de dicha capilla, donde se insiste en la obligación de celebrar, con el ornato y decoro preceptivo, el servicio litúrgico y religioso en favor de lo reyes allí sepultados (AHN, Consejos, lib. 2, 276v-283r). Ambos documentos han sido publicado por J. GARCía ORO y M. J. PORTELA SILVA, Felipe II y el Patronato.., pp. 620-622 y pp. 641644. Por nuestra parte añadimos los documentos sobre el tema del AGS. Patronato Eclesiástico, leg. 42, donde se recogen las mejoras para el funcionamiento de la capilla efectuadas en 1594, siendo capellán mayor el licenciado Francisco Ruiz de Velasco

${ }^{17}$ De hecho, en un documento conservado en la Biblioteca Nacional de Madrid, Raros, cod. 59, f. 67, se insertan referencias sobre la capilla de los Reyes Nuevos, en el que el capellán mayor de dicha capilla, en contestación a una carta de Felipe II, aporta al monarca la relación del oficio que se celebra en ese recinto funerario toledano para que sea motivo de análisis por parte del rey y para su posible utilización en El Escorial. Datos publicados por R. DíEZ DEL CORRAL, Arquitectura y mecenazgo. La imagen de Toledo.., p. 89. sustituida por una mejora de la capilla tardo-gótica, efectuada entre 1589-1590 ${ }^{18}$.

Tampoco se quedó a la zaga la ciudad de Sevilla, que en 1577 -1579 promovió el traslado de los cuerpos reales de San Fernando, Alfonso X, la reina Beatriz de Suabia y los Infantes, a la nueva Capilla Real, concluida en el interior del templo mayor hispalense por esos años ${ }^{19}$. El solemne cortejo que acompañó esta magna ceremonia fúnebre es un buen exponente de los deseos de exaltación de las hondas raíces históricas de la Monarquía castella$\mathrm{na}^{20}$. El tema se repite poco después en Córdoba, cuya capilla real también fue reformada en 1583.

Al hilo de todos estas intervenciones vinculadas con decoro de los enterramientos regios y con el Patronato Real y muy especialmente en relación con el magno proyecto de transformar el Escorial en recinto funerario de reyes hispanos, se justifica el primordial interés mostrado por Felipe II por el antiguo panteón de los reyes medievales sito en la abadía de San Isidoro de León.

Coincidiendo con la construcción del Escorial, y en los mismos años en los que se procede al traslado de los primeros cuerpos reales al "panteón de prestado" escurialense, el rey muestra gran interés por la disponibilidad de las rentas de la real colegiata leonesa ${ }^{21}$. Así se constata en una cédula

\footnotetext{
${ }^{18}$ J. García Oro y M. J. PORtela Silva, Felipe II y el Patronato, pp. 573-574.

${ }^{19}$ La capilla se había iniciado en 1551 bajo la dirección y trazas de Martín de Gainza. Sobre este recinto remitimos a A. J. MoRAles, La Capilla Real de Sevilla, Sevilla, 1979, p. 44 y ss; A. J. MORALES, "La arquitectura en los siglos XVI, XVII y XVIII" en AA.VV, La catedral de Sevilla, Sevilla 1991, pp. 173.216.

${ }^{20}$ J. García Oro y M. J. PORTEla SILVA, Felipe II y el Patronato, p. 620.

${ }^{21} \mathrm{AHN}$, Consejos, lib. I, ff. 237v-238, citado por GARCía ORO y PORTELA SILVA, Felipe II y el patronato, p. 579.
} 
real, dada en El Escorial y fechada el 3 de agosto de 1573, donde se solicitan los datos pertinentes que le permitan saber las posibilidades económicas para reformar y ampliar la capilla de Santa Catalina o la "capilla de los reyes", como por entonces se denominaba al panteón románico isidoriano. Se repetía el procedimiento llevado a cabo en otras capillas reales, como las de Toledo, Sevilla o Granada, ya mencionadas, en las que también el monarca quería mantener el control de su funcionamiento para que éste respondiera al ornato y decoro debido a los egregios antepasados reales.

Es posible que el viaje de Ambrosio de Morales a tierras leonesas y en especial, la detallada visita que efectúa a la colegiata y panteón isidoriano, tuviera mucho que ver con la voluntad de Felipe II de conocer con detenimiento las características, el número y el estado de conservación de los sepulcros de sus precedentes regios asturleoneses, bien con ánimo de efectuar el traslado de alguno de ellos hacia El Escorial, como inicialmente se había pensado en Toledo, o bien con el deseo de mejorar la capilla funeraria leonesa dentro de su programa de exaltación dinástica y en consonancia con la concepción castellanista y centralizada de la Monarquía. De hecho Morales se detiene de forma pormenorizada en la ubicación, disposición y relación de cada uno de los epitafios de las sepulturas del Panteón, subrayando siempre en ese listado el nombre del rey o reina, su parentesco, genealogía y datación cronológica, aspectos que, sin embargo, pasa por alto cuando se refieren a infantes o personalidades no vinculadas directamente a sucesión monárquica ${ }^{22}$.

\footnotetext{
${ }^{22}$ Ambrosio de MORALES, Viaje a los reinos de León, Galicia y Principado de Asturias, Madrid, 1765, ed. facsímil, Oviedo, 1977, pp. 41-48. Los datos con las inscripciones de los sepulcros y lápidas figuran ampliamente reseñados en esta obra, no nos hacemos eco
}

El texto de Morales nos proporciona también interesantes noticias sobre la disposición de los sepulcros en la capilla leonesa en el siglo XVI. Según su descripción, estaban colocados en dos alturas $\mathrm{u}$ órdenes hasta un total de 22, separando los que se ubican al lado de la epístola, de los del evangelio, a los cuales se sumaban los dispuestos en la parte baja, quasi nada levantadas del suelo y no tiene más que los nombres y no son reyes ni infantes, más otros tres lucillos arrimados a la pared y otros en un medio cubo de muro bajo al lado del evangelio ${ }^{23}$. En consecuencia, el ordenamiento de las sepulturas regias que describe Morales no seguía un esquema demasiado ordenado y el conjunto del recinto parece haber estado ocupado plenamente por tales cenotafios, lo que resultaba incómodo y no muy del agrado de personalidades clasicistas o de figuras, que, como Felipe II, buscaban el decoro y la dignidad de sus antepasados reales. Esta idea fue posiblemente la que Morales trasladó al monarca, tal y como él lo refiere en su texto, cuando afirma:

... porque están los sepulcros llanos y muy juntos unos de otros...y no se dice de ordinario Misa allí, porque como están las sepulturas muy juntas con el Altar, hay poco espacio y también se teme el entrarse gentes alli a la Misa y perderse aquel acatamiento... La capilla es oscura y no puede estar solada ni adrezada por las paredes, según son muchas las sepulturas reales ${ }^{24}$.

Las palabras del cronista del siglo XVI describen con veracidad la inadecuada disposición de los entierros medievales dentro del panteón, en la que prima un excesivo amontonamiento. Tenemos constancia documental y gráfica de este hecho en los diseños aportados por los proyectos

\footnotetext{
detallado de ellos por no tener un valor especial para nuestro trabajo, sin embargo, ofrecen un alto interés histórico y documental.

${ }^{23}$ Ibídem, p. 45.

${ }^{24}$ Ibídem, p. 42.
} 
de traslado y reforma del panteón de 1590 y 1692 , respectivamente, sobre los que versa parte de este estudio (Figs. no 1 a 6). En las imágenes dibujadas en el citado proyecto de 1692 es donde mejor apreciamos tal disposición, ya que en él se nos ofrece la ubicación de los sepulcros dentro del espacio funerario románico, tal y como aún permanecían en el siglo XVII, sin haber experimentado sustanciales modificaciones respecto de la época medieval ( Figs. n 1-3). Si observamos bien el dibujo es evidente que Morales no miente, su colocación es desordenada, están agrupados en el centro del recinto sin apenas dejar espacio libre en su interior para la óptima circulación de personas y oficiantes, y es lógico que Ambrosio de Morales, como hombre del renacimiento, elevara sus quejas por los impedimentos litúrgicos que ello suponía y por la ausencia de decoro y orden que se constata en esta representación gráfica ( Figs. 3-5).

Ante esta situación no es de extrañar que el rey decidiera el traslado a la capilla mayor o buscara la forma de mejorar el recinto funerario, como lo había conminado en otros ejemplos análogos, lo que sin duda ordenó en esos años, y a cuyo propósito responden los proyectos de traslado o modificación del pantéon y capilla de Santa Catalina, realizados por Juan del Ribero y por Baltasar Gutiérrez sobre los que se centra nuestro estudio.

Del interés del monarca por la mejora y decoro del espacio sacro leonés que guardaba los restos de sus antecesores medievales se hacen eco los canónigos de San Isidoro, en su reunión capitular celebrada el 14 de abril de 1574, en la que se acuerda que se vaya a Madrid a llevar la información de la capilla de los reyes que pide y manda Su Majestad por su cédula ${ }^{25}$. La cuestión debía ser

\footnotetext{
${ }^{25}$ ASIL, I-e-74.b. Actas capitulares, 14 abril, 1574, f.
} $8 \mathrm{v}$ poco grata a los religiosos isidorianos, quienes trataran por todos los medios de entorpecer el proyecto. Por ello, el 24 de noviembre de 1574, fue el corregidor de León, Diego Luxán de Ayala, el encargado de comunicar a la colegiata los deseos de Felipe II por ampliar y beneficiar el recinto funerario áulico, empleando para ello los frutos de la abadía, que estaba vacante desde junio de 1573 por muerte del abad don Francisco Miranda ${ }^{26}$. La disposición de tales rentas se justificaba conforme a un Breve Pontificio por el que el monarca, en virtud del patronato regio, podía disponer de tales beneficios, cuya suma ascendía a 822.657 maravedís ${ }^{27}$. La idea no gustó a los religiosos leoneses, quienes como celosos guardianes de las antiguas reliquias regias, veían que con tal disposición se les privaba de una considerable fuente de ingresos con los que remediar las otras obras que por entonces se llevaban a cabo en la abadía, como eran las dependencias del priorato y la escalera monumental ${ }^{28}$. Por todo ello, a principios de 1575 el cabildo de San Isidoro comisionó al licenciado Santollano, para llevar a la corte y al secretario real Gaztelu, un presente, para acabar el negozio y rematarlo y para rematar en las cuentas que se enviaron al rey por el corregidor sobre la traza y planta de la $\operatorname{casa}^{29}$.

Los intentos de detener o, cuando menos, dilatar la operación debieron surtir efecto y el tema no volvió a tratarse hasta el nombramiento del nuevo abad, don Pedro Zúñiga y Avellaneda, en 1576. Es entonces cuando la cuestión se complica aún más,

${ }^{26}$ Ibidem, f. 18v

27 AGS. Patronato eclesiástico, leg. 42. Así se especifica en febrero de 1589 por la cédula real y en 15 de mayo de 1590

${ }^{28}$ Sobre estas obras remitimos a J. RIVERA BLANCO, La arquitectura en la segunda mitad del siglo XVI en León, León, 1982.

${ }^{29}$ ASIL, I-e-74.b. Reunión capitular de 4 febrero 1574 , f. 25 v. 
debido a la reclamación efectuada por don Pedro de Zúñiga de los 2.000 ducados que le corresponden, provenientes de la abadía leonesa que a partir de esa fecha iba a ocupar. Dicha solicitud era justificada por el abad mediante el firme propósito de contribuir a la reforma de la comunidad y realizar las obras en la capilla real. Una vez más los capitulares leoneses, recelosos de tales intenciones, hacen saber que dicha cantidad está depositada por orden del rey y no pueden disponer libremente de ella, siendo necesaria la autorización regia ${ }^{30}$. Todos estos aspectos alargaron el proyecto $\mathrm{y}$, de hecho, éste no vuelve a tratarse en la colegiata hasta dos años después.

En efecto, en 1578 el cabildo isidoriano recibe nueva carta del licenciado Santollano en la que se les comunica que sigue vigente la intención del rey, ... de hazer la capilla mayor [que] según su mandato y orden está trazada.. a fin de mudar a ella los sepulcros reales que en esta casa están en la capilla de Santa Catalina, en el claustro ${ }^{31}$.

Las obras para tal empeño comenzaron en 1580, sirviéndose de los 2.000 ducados disponibles y conforme a sendas cédulas reales fechadas en Lisboa el 11 de agosto y 21 de octubre de 1581, respectivamente ${ }^{32}$.

${ }^{30}$ ASIL, I-e 74, b. Actas capitulares de 31 de octubre de 1575. En la reunión capitular de ese día se trata el tema de la petición formulada por el nuevo abad, Pedro Zúñiga y Avellaneda, hijo de los Condes de Miranda, a través de su criado Baltasar de Mendoza, del empréstito de los 2000 ducados. El cabildo responde que tal cantidad está depositada por orden del rey y habrá de tratarse con él tan delicada cuestión.

${ }^{31}$ ASIL, caja 74-b, Actas capitulares de 13 de mayo de 1578 , f. 136v. También se han hecho eco de esta cuestión los trabajos de J. PÉREZ LlamAZARES, Historia de la colegiata, p. 158; J .J. MARTín GONZÁLEZ, "El Panteón Real de San Isidoro. Dos proyectos fracasados de reforma y un reconocimiento de sus restos", Boletín de la Sociedad Española de Excursiones, IV, 1950, pp. 157-166 y J. RIVERA BLANCO, La arquitectura de la segunda mitad del siglo XVI en León, León, 1982.

32 J. García Oro y M. J. PORTela Silva, Felipe II y el patronato.., p. 579.
Sin embargo, la grave enfermedad del abad D. Pedro de Zúñiga, y sobre todo, el hecho de que la idea de transformar la capilla mayor para trasladar a ella los sepulcros reales no gustaba a los capitulares, de talante bastante conservador, determinó que el tema se orientara exclusivamente a la modificación y ampliación del Panteón, con la anexión de la capilla contigua, tratando de disponer los cenotafios regios con el mayor decoro y ornato posibles, en consonancia con las ideas y el patronato de Felipe II, pero sin modificar la capilla mayor $\mathrm{y}$, menos aún, trasladar a ella los entierros, ya que tal hecho significaría dejar el viejo espacio áulico isidoriano vacío de contenido y carente de simbolismo. Los impedimentos y dejaciones de los canónigos determinaron al monarca español a poner el tema en manos de corregidor leonés, Francisco de Berasategui y del obispo Trujillo.

Así en 23 de febrero de 1589 y en marzo de 1590 el rey manda al corregidor y al obispo Trujillo, que los 822.657 maravedís, que suman las rentas del período en que la abadía isidoriana estuvo vacante tras la muerte de D. Gregorio Miranda (desde junio 1573-diciembre 1574), los guarden a buen recaudo ${ }^{33}$ y se empleen exclusivamente en reparo y adorno de la Capilla de Santa Catalina, para lo cual les autoriza a que sean ellos los encargados de decidir las trazas y soluciones que mejor les pareciere, además de tomar las cuentas al convento sobre las cantidades invertidas por los capitulares y en función de todo ello provean:

como todos los dichos maravedis se gasten y distribuyan luego en reparar lo que al dicho obispo y a vos pereciere ser mas forçoso y necçe-

\footnotetext{
${ }^{33}$ De hecho el corregidor tenía guardado en depósito dicha cantidad en la torre de los antiguos palacios reales de León, en la calle de la Rúa, en un cofre con dos llaves, según se desprende del mismo documento ( AGS, Patronato eclesiástico, leg. 42 cédula real de 15 de mayo de 1590).
} 
sario en la dicha capilla, de manera que quede con la mas deçencia que se pueda, sacándolos, para este efecto, de la dicha torre [del palacio real de León] donde los pusistes, poco a poco, ansí como se fueren gastando, sin dar lugar a que se gasten, ni conviertan en otra cosa alguna, sino en los dichos reparos y avisarme eys de lo que fuere haziendo para que yo sepa como se pone en execuçión $n^{34}$.

A este momento y a esta idea deben corresponder las trazas conservadas en el Archivo General de Simancas en las que figuran cinco dibujos con el conjunto de la iglesia, el panteón y dependencias de la colegiata leonesa $^{35}$ ( Figs. 1-6). De hecho el 15 de marzo de 1590 de la cantidad reseñada, el rey reconoce que ya se habían gastado 18.000 maravedís ..con çiertos maestros de cantería en las trazas que se hicieron por mi mandado para la obra de la dicha capilla y en costas del escrivano que tomó las quentas ${ }^{36}$.

Ante la evidente ejecución del nuevo panteón, la colegiata se sintió amenazada en sus intereses y mantuvo su actitud de rechazo a las modificaciones arquitectónicas, planteando un duro debate en el seno de la institución religiosa. El 4 de abril de 1590 el prior de la colegiata comunica a los

\footnotetext{
${ }^{34}$ AHN, Consejos, lib. 2, ff. 406v-407r. Una copia del mismo también se guarda en AGS, Patronato eclesiástico, leg 42. Donde ha sido consultado por nosotros. Deseamos agradecer a la dirección de este archivo la autorización para su consulta y publicación. Parte de este documento ha sido publicado por J. GARCÍA ORO y M. J. PorTela SiLVA, Felipe II y el Patronato.., pp. 668669.

35 AGS. Patronato eclesiástico, leg. 42. M.P. y D, VIII38; VIII-39; XX,6; XX-7. Así lo han considerado también los estudios que han tratado el tema, como los de J. J. MARTín GONZÁlez “El panteón Real de San Isidoro..", p. 159; J. RIVERA BLANCO, La arquitectura ..., AAVV, Herrera y el clasicismo, Catálogo de la exposición.., Valladolid, 1986, p. 232-234; J. GARCÍA ORO y M. J. PORTELA SILVA, Felipe II y el patronato real.., p. 578; M. A. Aramburu-Zabala, C. Losada y A. Cagigas, Biografía de Juan de Herrera.., p. 371.

${ }^{36}$ AHN, Consejos, lib. 2, f. 407r; AGS, Patronato eclesiástico, leg 42.
}

capitulares la llegada de unas cartas remitidas desde la corte por don Antonio Villafañe y Garnelo de Velasco en las que se les dice "como su Magestad ha pedido en el negozio del depósito que se gaste de presente en el decoro y ornato de la capilla de los reyes ${ }^{37}$. Los canónigos optan por decidir en capítulo, pero ante las dudas surgidas, la variedad de opiniones que ofrecen los informes, las indecisiones del obispo Francisco Trujillo y del corregidor Francisco Berasategui, se pospone el acuerdo. Finalmente el 17 de abril el prior de la comunidad religiosa, remite a Felipe II un comunicado por el le ruega mande lo que fuere servido y como del parecer de la Real Casa de San Isidoro paresció a todos que atenta la tradición que en esta casa ha habido y a lo que resultó de las nuebas diligencias echas, como fue el descubrir algunos luzillos.,..no se torne su magestad por descuido se incorpore el dicho pedazo.. ${ }^{38}$.

Lo discutido tanto por el prior y los capitulares isidorianos, como por el resto de las autoridades y personalidades relacionadas con el tema, era el modelo de panteón que se desea imponer en León. La cuestión suscitaba una amplia variedad de criterios y diversidad de intereses, ya que ello comportaba aspectos funcionales, estéticos, económicos, religiosos y litúrgicos, difíciles de compaginar. A ello se sumaba que los proyectos, ensayos y trazas presentadas por los maestros arquitectos, Ribero y Gutiérrez, no resolvían la cuestión, al estar ampliamente condicionados por las presiones y por el general rechazo a un cambio sustancial del recinto funerario, limitándose a soluciones muy parciales y poco creativas. De hecho así lo reconocen los propios religiosos leoneses:

Sobre lo qual ubo diferentes paresceres y para los concordar y ver lo que mas convenga al

\footnotetext{
37 ASIL, I-e 74,b, Actas capitulares de 4 de abril de 1590, f. 325v.

${ }^{38}$ Ibidem, f. 327v.
} 
serviçio del rey nuestro señor y buen adorno de la dicha capilla mandaron a los dichos maestros piensen y consideren sobre la traça y traças que en esto se podran dar que mejores sean para el buen expediente de este negozio.

El señor prior dio quenta a los dichos señores obispo y corregidor de deçir que en aquella parte que se pretendía añadir avía algunas sepulturas antiguas y que avía tradición en la dicha casa y monasterio, aunque no por papeles ni scripturas, de que aquella parte se avía atajado para los entierros de algunas personas reales que están en dicha capilla, como paresció por un rotulo de un túmulo que solo ay en el dicho pedaço, que dize en la forma y manera siguiente: "hic requiesat donna Toda uirttibus et diuitiis ornata filia Nunii Melendi excelentisimi militis quia regibus fuit secundus in Hispania era millesima ducentessima sexagesima prima quinto idus aprilis". Y que mirasen si esto era algún inconveniente

Las citadas trazas encargadas a los maestros, conservadas en el Archivo General de Simancas, si bien carecen de autoría y fecha exacta, a nuestro juicio son el resultado de los planteamientos realizados por Juan del Ribero y Baltasar Gutiérrez ante la exigencia del monarca de reformar la capilla y de ubicar los sepulcros reales en un lugar más digno y de manera más ordenada y armoniosa. Sus dibujos responden a los proyectos e ideas que intentaron llevar a término el corregidor y el obispo de León, verdaderos intermediarios del Felipe II. Así se constata en la documentación adjunta donde ambos maestros figuran expresamente mencionados como autores de las trazas con las dos propuestas que se barajaban, una, la que más agrada a ambas autoridades locales y a los arquitectos, contemplaba la ampliación de la capilla real mediante la unión del espacio inmediato a ella, es decir la anexión de la capilla de Santa Catalina; la otra, más acorde con los esquemas conservadores de los religiosos isidorianos, era dejar todo como estaba y limitarse únicamente a modificar la colocación de los cenotafios de forma más decorosa y funcional. Así se especifica el 26 de abril de 1590:

..y les paresció que los maestros Baltasar Gutiérrez y Juan del Rivero hagan dos traças, una, en la forma en que la dicha capilla está y como se podrán mejor repartir y distribuir tanta cantidad de túmulos; y otra, con la extensión y anchura, con los mismos repartimientos quitando el dicho atajo de buena mano y rasguño y que todo se llebe a su merced con las diligencias hechas...para que su Merced mande y hordene lo que más a su real serviçio convenga... ${ }^{39}$.

Lo presentado por Gutiérrez y Ribero Rada fueron un total de cinco dibujos, que el obispo y corregidor remitieron al rey para que fuera él quien decidiera ante las dudas y problemas planteados ${ }^{40}$. De estos

${ }^{39}$ AGS, Patronato Eclesiástico, leg. 42. Un párrafo más adelante, se vuelve a insistir en la autoría de ambos artistas, cuando se confirma que el secretario (Baltasar de Peñaranda) y el escribano ( Hernando de Ordás) habían notificado lo ya acordado a los dichos Baltasar Gutiérrez y Juan del Ribero, para que por mandado de los señores obispo y corregidor, lo hiciesen con mucha brevedad.

${ }^{40}$ AGS, Patronato Eclesiástico, leg. 42. El escrito dirigido al rey por el obispo de León y por el corregidor Francisco de Verasátegui es muy aclaratorio del tema y dice así: En recibiendo las cédulas reales de V.M. sobre el adorno de la capilla de Sancta Catalina en San Ysidro desta çiudad, hicimos juntos las diligencias que convenía, viendo y examinando muy en particular su sitio y communicando con el prior y religiosos antiguos de aquel convento y con los maestros de obras, y reparamos en la execución asta dar parte a V.M. de dos medios que se nos ofrecen, el uno es adornar la capilla con el sitio que haora tiene y no más; el otro, es que a los pies de la capilla Real está otra pieça que antiguamente fue apartada della con un atajo y es el mismo edificio y la mesma traça en pilares, bóbeda y en alto y ancho y quitando el atajo quedaría una muy buena pieça, anchurosa, sin diferencia alguna de la una parte a la otra, y podríanse disponer los sepulchros reales con mucha gracia. Representasenos que para aquella antigüedad sería de estima dibidieron esta pieça, a nuestro paresce, $r$ para entierro de personas allegadas a la casa Real de V.M., porque dentro de la capilla Real, a su entrada, está un sepulchro lebantado de un cavallero y está otro tanbién lebantado de una hija suya, en aquella parte atajada ay otros entierros en ella, pero bajo 
cinco dibujos, uno corresponde a la planta general de la iglesia, incluidos el claustro, panteón y otras dependencias de la colegiata leonesa. El segundo responde a la idea de ampliar el panteón real anexionando la capilla contigua. El tercero tan solo representa el panteón con los túmulos dispuestos en forma de $U$, es decir la propuesta más conservadora. Los otros dos se relacionan exclusivamente con los modelos de sepulcros, sin entrar en cuestiones espaciales, $\mathrm{ni}$ arquitectónicas ( Figs. oํ 1 a 5 ).

En el primer dibujo se representa el conjunto de la planta de la iglesia y de la colegiata de San Isidoro, tal y como se encontraba la fábrica en el siglo XVI (Fig. $\mathrm{n}^{\mathrm{o}}$ 1). Uno de los aspectos más significativo es la proyección de la cabecera del templo como espacio cuadrangular con testero plano, es decir, alterando brevemente la forma de la capilla mayor que había sido levantada por Juan de Badajoz el Viejo, a comienzos del siglo XVI, con bóveda de crucería. En el mismo dibujo se anotan las leyendas y referencias a diferentes partes y espacios de la abadía, entre ellos el que corresponde al panteón o "capilla real donde están los cuerpos reales", así como "la capilla que se a de hañadir a la real" (capilla de Santa Catalina). También se señalan las medidas, en pies, de distintos recintos del edificio ${ }^{41}$ (Fig. $\mathrm{n}^{\mathrm{o}} 1$ ).

de tierra. Hicimos diligencia para entender si ay algún apellido o dueño de aquél pedaço y no le ay, questo confirma mas ser cosa de los inclitos progenitores de V.M. Ynviamos a V.M. las traças detrambos medios y de cómo en cada uno de ellos se distribuyran los sepulchros reales y juntamente el procesillo que hicimos.

V.M. elixa el que más se sirba que imbiandonos la resolución con mucha brebedad adornaremos el que V.M nos mandare..En León y de mayo 30. 1590. (Firmado por el obispo de León y el licenciado Francisco de Verasategui)

${ }^{41}$ En el dibujo también se anotan otros datos de interés relacionados con la colegiata y abadía isidoriana. Así por ejemplo, se especifica la medida de 30 pies de la nave mayor y 14 pies para cada una de las latera-
Es evidente que esta primera traza tiene como finalidad la de presentar las medidas de los diferentes espacios de la abadía con el fin de decidir en cuál de los dos recintos sacros, (cabecera o panteón), deben disponerse los sepulcros regios para conferirles mayor dignidad. Si se elige la cabecera de la iglesia, la idea exigiría la previa transformación de su espacio cuadrangular (35 pies de lado), tal y como se ha dibujado, pero el resultado se aproximaría a los esquemas estéticos y litúrgicos queridos por monarca, y muy cercanos al círculo clasicista de Juan de Herrera y al pensamiento contrarreformista, materializado tanto en la iglesia del Escorial, como en la colegiata de Valladolid, obras del arquitecto real ${ }^{42}$. Con esta solución se creaba

les; la capilla mayor mide 35 pies de lado, mientras que los dos ábsides laterales, referidos como capilla de San Joan y capilla de San Pedro, respectivamente, miden 11 pies; en cuanto al crucero, se especifica que tiene 100 pies de largo (cifras estas últimas escritas en número romanos -, XI y $C$ pies- a diferencia del resto que se anotan en número arábigos). Entre las dependencias y capilla mencionadas en las leyendas de este dibujo destacan: la capilla real, ya reseñada en el texto, y la de Santa Catalina, junto a ella se anota la de Santa Mónica, ya en el claustro, en cuya panda de poniente también se abren la capilla de los castellanos, la capilla de los Reynosos y bodega del convento. Al lado del panteón real se han dibujado los espacios correspondientes a las antiguas dependencias reales medievales, transformados en el siglo XVI en librería, oficinas y apartamentos del convento comunicados a través de una vano en esviaje con la iglesia. Finalmente, como dato curioso constatamos la prioridad concedida a la Puerta del Perdón en la que se anota: puerta principal que sale a la plaza y responde al mediodía, sin embargo, sobre la actual puerta principal de la iglesia ( Puerta del Cordero) no se hace ninguna indicación.

${ }^{42}$ La capilla mayor de testero plano y cuadrangular permitía quizás ubicar en una cripta o panteón los enterramientos de los viejos reyes leoneses. El espacio resultante no estaba muy alejado de las medidas que inicialmente se otorgaron al panteón del Escorial, (36'6 pies de diámetro) si bien la forma centralizada y redonda de éste, según las trazas de Juan Bautista de Toledo y de Juan de Herrera de 1562 y 1572, respectivamente, difiere bastante de la cuadrangular leonesa. Sobre el primitivo panteón de San Lorenzo remitimos 
un espacio funerario áulico más digno y más del agrado de Felipe II, donde los sepulcros de sus antepasados, los reyes leoneses, cual reliquias o cuerpos santos, se ubicarían cerca del altar, junto a las reliquias del santo patrón Isidoro, y expresarían la unión de lo áulico y sagrado, como también se hacía en el panteón escurialense.

La cabecera recta proyectada en el dibujo de la iglesia leonesa respondía además a un modelo ampliamente conocido por Juan del Ribero Rada, a quien con toda seguridad podemos considerar el autor de la traza isidoriana, cuyo esquema ensaya ahora y repetirá en otros tantos ejemplos levantados por él por estos mismos años, como son la iglesia de San Marcelo o la del convento de Concepcionistas en León, y el templo de las Huelgas de Valladolid (1579).

No obstante, si se optaba por dejarlos en la antigua capilla real o panteón medieval, como pretendían otras voces, su angosto espacio requería la ampliación mediante la anexión de la contigua capilla de Santa Catalina, de manera que de esa forma se lograba la creación de un recinto funerario de unos cuarenta pies de largo y treinta de ancho. Una opción que preferían tanto los arquitectos como el obispo y corregidor leonés, pero no el prior de la colegiata, reacio a todo cambio.

Conforme a este propósito, el segundo de los dibujos ofrece la imagen de la capilla de Santa Catalina y de Capilla Real anexionadas, con la ubicación de los cenotafios reales dispuestos en forma de una larga $\mathrm{U}$, centro de las dos capillas, ocupando un espacio de 40 pies de largo por 11 de ancho, mientras que el total de la superficie lograda con la anexión era de 54 pies de largo por 30 de ancho, es decir, superior al de la

al trabajo de A. Bustamante, "El Panteón de El Escorial. Papeletas..", p. 163. capilla mayor del templo (Fig. $\mathrm{n}^{\mathrm{o}} 2$ ) $^{43}$. Todo ello facilitaba la colocación regular, ordenada y des entierros conforme a los esquemas clasicistas y marcadamente diferenciada con la irregular disposición que por entonces tenían los cenotafios medievales

La presentación de otros tres dibujos relacionados exclusivamente con la planta y traza de la capilla real o panteón, sin anexiones ni ampliaciones, nos hace suponer que fue esta la elección finalmente tomada y, por lo mismo, hubo de abandonarse la idea de trasladar a la capilla mayor los sepulcros reales, tal y como hubiera deseado Herrera o, en su defecto, ampliar el viejo recinto medieval, como abogaban los arquitectos. Los capitulares no querían, ni tampoco los vecinos de León, como afirmaba el corregidor Berasategui, alterar la vieja tradición histórica del lugar y esa idea fue finalmente la que más peso tuvo. En consecuencia, el tercero de los dibujos responde a la traza de la capilla real o panteón isidoriano con la disposición de los sepulcros en su interior, pero sin proceder a la unión del recinto colindante de la capilla de Santa Catalina. Es posible que tal ubicación correspondiera a la que tenían originariamen-

\footnotetext{
${ }^{43}$ En el dibujo de la planta de Capilla Real, se presenta la disposición de los cenotafios y el espacio resultante tras la unión de la dos capillas (la de los Reyes, o panteón propiamente dicho, y la de Santa Catalina), así como el altar, las rejas que lo separan del claustro y las dos puertas de entrada a la nave de la iglesia, una a la nave central y, la otra, a la nave lateral, que por entonces debía estar cerrada ya que de ella se especifica: esta puerta e ha de abrir agora de nuevo. El dibujo también nos ofrece medidas y aspectos de cierto interés sobre este tema. Entre las leyendas, anotamos: Esta es la cama o pedestal que anda por estas tres partes desta capilla real, según esta traza que de nuevo se da, que es por los dos lados de ella como aquí parece y por el testero que es este donde ba esta letra y sobre ella an de yr puestos los veynte y dos lucillos como lo muestran los dos alzados marcados con la $A-B$. Así mismo, entre las medidas, se especifica Huella y ancho de esta capilla que son 30 pies; El huello desta capilla es este cuyo largo queda en estos 40 pies y en el ancho XI. Tiene toda esta capilla de largo 54 pies, poco mas o menos y de ancho 30 pies, poco más o menos.
} 
te los cenotafios antes de intentar su modificación (Fig. $\mathrm{n}^{\mathrm{o}} 3$ 3) $^{44}$, o, en todo caso, el dibujo trataba de manifestar gráficamente $y$ con medidas exactas que la colocación de los sepulcros en el antiguo panteón, sin anexionar la capilla contigua, resultaba angosta y estrecha y por lo mismo contra la idea de magnificencia y decoro que el Felipe II buscaban. Era por otro lado, la propuesta que menos gustaba a los arquitectos, quienes así los especifican en el propio dibujo:

El huello que queda desta capilla no tomando esta otra, que son estos XX pies y en ancho $X$, quedan estos lucillos y la postura suya con mucha desapacibilidad, como en ellos parece de más y allende quedan muy apretados y juntos ${ }^{45}$.

De resultas de todo lo anterior, se hace un ensayo o proyecto de la disposición y modelo de los 22 sepulcros, siempre manteniendo la forma de U. De las dos trazas conservadas en Simancas, una, lleva 22 sepulcros, la otra, sin embargo, presenta 19 en el centro más dos en cada una de las dos paredes laterales, lo que sumarían un total de 24 .

El tipo de sepulcro es muy sencillo y su disposición seriada en forma de $U$ recuerda a los dibujados en el texto ya citado de las Memorias de San Jerónimo donde se representan los del Panteón de Prestado de la iglesia vieja de El Escorial ${ }^{46}$. Una vez más

\footnotetext{
44 De hecho en el dibujo se especifica : Esta es la parte que se ha de dar y añadir agora a esta capilla real, que hazen estos 29 pies de largo y en hancho 20 pies y con esto queda esta capilla en el dicho largo de los 54 pies. Pero también se dan las medidas de la capilla real: El huello que queda desta capilla no tomando esta otra, que son estos $X X$ pies $y$ en ancho $X$, quedan estos lucillos y la postura suya con mucha desapacibilidad, como en ellos parece de más y allende quedan muy apretados y juntos. (AGS, Patronato eclesiástico, leg. 42, M.P. y D.)

45 Ibidem.

46 Dibujos publicados por A. BUSTAMANTE, “El Panteón de El Escorial. Papeletas.." pp. 165 y 169
}

se demostraba que hasta León habían llegado los ecos del Escorial.

Ninguna de las tres posibilidades de reforma del panteón leonés que estaban representadas en estas trazas tuvieron plena y unánime aceptación. Por lo cual se determinó recurrir a un experto en la materia, sugiriéndose remitir los dibujos a Juan de Herrera para que diera su parecer como reconocido arquitecto en la materia, lo que finalmente se hizo en mayo de $1590^{47}$.

El informe que, sobre las trazas, redactó Juan de Herrera, fechado en Madrid, el 4 de enero de 1591, es totalmente negativo. En un breve escrito, el arquitecto escurialense, señala cuatro grandes defectos que, a su juicio, hacen inviable la obra propuesta, ni siquiera en el hipotético caso de anexionar ambos espacios medievales. En primer lugar, se alude cuestiones de estética y decoro relacionadas con la función litúrgica del espacio sacro funerario, afirmando textualmente que:

"lo primero que la traza que imbiaron es muy indecente para poner en ella los cuerpos reales, porque ni tiene autoridad, ni grandeza, ni con ella se puede acomodar la capilla para que quede el servicio della con capacidad para hazer allí los oficios divinos, aunque se añada la otra capilla que está a los pies de la de los Reyes ${ }^{48}$.

En segundo lugar, tampoco le agradaba la disposición de los féretros y lucillos en formando una $U$ en el centro, ya que, según este artista, se alteraba el ornato de la capilla, cuyo reducido espacio quedaba seriamente perjudicado y empequeñecido ${ }^{49}$.

\section{-}

También han sido motivo de atención y publicación en el reciente catálogo sobre Las trazas de Juan de Herrera, Madrid, 2001, p. 320.

${ }^{47}$ AGS, Patronato Eclesiástico, leg. 42.

${ }^{48}$ AGS, Patronato eclesiástico, leg. 42.

${ }^{49}$ Ibídem, en este caso el texto de Herrera dice literalmente: El segundo [inconveniente] que haziéndose el pedestal como se muestra en la traça y puniendo ençima los 
Si bien debido a las características del recinto medieval y al elevado número de sepulcros existente, era la solución más idónea y la que podría mejorar sus condiciones, ya que dejarlo como estaba suponía mantener la angostura e irregularidad a la que hacían referencia Ambrosio de Morales y los contemporáneos que visitaron el edificio. Por ello dudamos que Juan de Herrera conociera personalmente la fábrica de San Isidoro. Probablemente emite su juicio a través de los diseños que le llegan, pero sin tener una idea verdadera de las dificultades y de la situación del panteón leonés.

El tercer problema $\mathrm{y}$, a su juicio, el mayor inconveniente, es el hecho de que tal obra implicaba el traslado temporal de los sepulcros a otro lugar de la colegiata, donde quedarían depositados hasta finalizar la nueva fábrica. Una cuestión que implicaría no solo grandes gastos, sino muchos embarazos y confusión, y costa, y, por ventura, no se haría con la deçencia que es razón $n^{50}$.

Por último, Herrera propone que para llevar a cabo una obra tan insigne lo más adecuado sería hacer una nueva la capilla mayor y transformarla en digno espacio funerario áulico, o, en todo caso, hacer en otra zona de la iglesia un nuevo panteón o recinto destinado a tal fin, con la autoridad, grandeza y pompa que se les debe a los cuerpos reales, sin duda un proyecto más ambicioso que el trazado, para el cual, según reconoce el propio Herrera, de momento no hay dinero ni de donde le haver ${ }^{51}$. Es evidente que en

\footnotetext{
lucillos todo lo que toman los lucillos de alto con el pedestal quedan soterrados los miembros y ornato de la capilla.

${ }^{50}$ Ibídem.

51 Ibídem.

...lo quarto, que para hazer una obra tan insigne como esta debría ser, no ay dinero, ni de donde le aver, y quando éste aya y se deyterminase en algún tiempo de hazer la obra, es menester o hazella en la capilla mayor, o en otro lugar de la iglesia que tenga la autoridad que se requiere, y
}

esta última determinación pesaba la idea del Escorial en la que él había tomado parte tan activa y, sobre todo, trataba de imponer las ideas clasicistas a favor de la plena adecuación de la función al espacio, tema sin resolver en las trazas que le habían sido enviadas desde León, ya que en éstas se pretendía por todos los medios adecuar las viejas estructuras medievales a una estética y a unas funciones litúrgicas para las que no habían sido levantadas. De hecho, las propuestas de Juan del Ribero y Baltasar Gutiérrez intentaban básicamente ampliar el espacio del panteón real, disponiendo los sepulcros perimetralmente, en forma de $\mathrm{U}$ y con poca altura, dejando libre el centro para el altar y actos litúrgicos, pero el resultado, como fue advertido por Herrera y también por Ambrosio de Morales, seguía siendo un recinto pequeño, oscuro, de escasas posibilidades litúrgicas cara a los fieles y sin mejorar demasiado el decoro de los sepulcros allí depositados. Es decir, el proyecto era contrario a óptima funcionalidad que exige la buena arquitectura, y como tal rechazado por Juan de Herrera. Ni siquiera el traslado del panteón a la cabecera tardogótica del templo isidoriano, tal y como figura en el dibujo posiblemente realizado por Juan del Ribero, y tal y como proponía Herrera, solucionaba demasiado el problema, ya que el espacio final resultante, por las propias condiciones de la fábrica medieval, también era angosto y hubiera sido preciso realizar una cripta bajo el presbiterio, repitiendo el modelo escurialense, lo que resultaba muy costoso e inviable en aquellas fechas para las arcas de la colegiata leonesa ${ }^{52}$ ( Figs. $n^{\circ}$ 3-6)

\footnotetext{
-

quando esta estubiere hecha pasar allí los cuerpos reales con la autoridad, grandeza y ponpa que se les debe a los cuerpos reales. En Madrid a 4 de henero de 1591. Joan de Herrera.

${ }^{52}$ De hecho Juan de Herrera también advierte que la escasez de medios económicos impide hacer la obra
} 
En función de todos estos inconvenientes, Herrera propuso que no se llevara a cabo la modificación del panteón leonés, una decisión admitida por el rey, quien el 30 de enero de 1591 ordenó al obispo y corregidor de León se pospusiera la obra y se mantuviera a buen recaudo el dinero en depósito a ella destinado ${ }^{53}$.

En consecuencia con lo anterior, los motivos para rechazar al proyecto no estaban fundamentados en el respeto a la arquitectura y pintura románica, ni tampoco en la admiración por el valor artístico del panteón medieval, tema por otro lado poco habitual en los hombres del renacimiento, sino que el rechazo se justificaba por razones de tipo litúrgico y por el respeto a lo que históricamente representaba el espacio, en cuanto que allí estaban depositados importantes precedentes de la monarquía hispánica que el rey quería legitimar dinásticamente. Fueron la historia, tan querida a los humanistas; la falta de decoro, la ausencia de "grandeza" y "autoridad" del proyecto, que criticaron las mentes clasicistas; y la liturgia y culto a las reliquias, defendidos por las ideas contrarreformistas, las razones que más pesaron a la hora de decidir la interrupción de la nueva fábrica. Entre la múltiple documentación del siglo XVI relacionada con el tema no hemos encontrado una sola referencia al valor artístico,

como es debido ...Que para hazer una obra tan insigne, como esta debría ser, no hay dinero, ni de donde le haver, y quando éste aya y se determinara algún tiempo de hazer la obra, es menester hazella en la capilla mayor.... (AGS, Patronato eclesiástico, leg. 42)

${ }^{53} \mathrm{AHN}$, Consejos, Lib. 2. Cédula real dada en Madrid el 30 de enero de 1591, f. 455v; AGS, Patronato eclesiástico, leg. 42. En este mismo documento se inserta otro dato relacionado con el tema, fechado el 21 de julio de 1593, por el que se despacha una real cédula para que Iñigo de Saravia, corregidor que agora es de la ciudad de León, cobrase del licenciado Verasatégui, su predecesor en dicho cargo, la cantidad de 804.657 maravedíes y los mantenga en su poder a buen recaudo y en depósito, hasta que el rey determinara que se habría de hacer con ellos. ni siquiera a las pinturas murales que hoy admiramos, lo cual encaja perfectamente con el sentir de la época y a nadie a de extrañar. Si afortunadamente el panteón real leonés se conservó fue gracias a su significación histórica y, por que no decirlo, a la falta de medios económicos suficientes que impidieron la ejecución de un nuevo recinto funerario de mayores proporciones y ornato, como de hecho pretende Herrera. Una cuestión que de nuevo se volvió a plantear un siglo después, en 1692, bajo los esquemas de magnificencia y ornato del barroco.

\section{EL NUEVO PANTEÓN REAL DE SAN ISIDORO DE LEÓN EN EL SIGLO XVII.}

Rechazado el proyecto de modificar la ubicación de los sepulcros reales y alterar la disposición interna del recinto medieval, el panteón isidoriano seguía ofreciendo los defectos ya aludidos en el siglo XVI, relacionados con la estrechez del espacio, la falta de decoro y la carencia de luz. Por tales motivos, durante el primer tercio del siglo XVII prosiguieron los intentos por mejorar la "Capilla Real y la de Santa Catalina", frustrados en la mayoría de las ocasiones por los problemas económicos que por entonces atravesaba el centro religioso. Así en 1621 los canónigos leoneses determinaron vender una hidalguía que el rey había concedido a la colegiata, para invertirla en reparos de la capilla de Santa Catalina, mártir, donde están sepultados algunos señores reyes $^{54}$. Unos años más tarde, en 1628 , ante una posible devaluación monetaria se solicita autorización real para emplear a una

-

${ }^{54}$ ASIL, Q. caja 252, no 3, Actas capitulares de 1 de diciembre de 1621. Siguiendo lo ya acordado en la anterior reunión capitular de 7 de abril de 1621, la hidalguía se vendió en esa fecha a Martín Ruiz Soler Melgrarejo, vecino de la villa de Cieza, del partido de Campo de Montiel, en precio de 43000 reales ante el escribano Juan Bautitra de la Torre. En representación del prior y cabildo isidoriano actuaron D. Lupercio de Quiñones y Diego de Pernia, canónigos. 
partida de dinero, al parecer depositada en moneda de vellón en el archivo de la institución isidoriana, para el adorno de la capilla de Santa Catalina donde descansan los santos cuerpos de sus antecesores ${ }^{55}$. Ninguna de estas intervenciones fueron de gran alcance, ya que se limitaron a pequeñas operaciones de adorno y reparaciones del recinto.

Por ello, desde mediados del siglo XVII, cuando ya había sido concluido definitivamente el Panteón de El Escorial con las ideas de Juan Bautista Crescenzi y de Juan Gómez de Mora, las diferencias entre la magna obra escurialense y el resto de los viejos recintos funerarios reales hispanos, como el de San Isidoro, se hicieron cada vez más acusadas a los ojos de sus contemporáneos. Tales diferencias se pusieron aún más de manifiesto tras la publicación de la Descripción breve del Monasterio de San Lorenzo el Real del Escorial de Fray José de los Santos en $1657^{56}$. En este impreso, en el que el Panteón escurialense ocupa un papel primordial, se ofrecen magníficos grabados que proporcionan un amplio repertorio

-

${ }^{55}$ ASIL, Q. caja 252, no 5 , Acuerdo capitular de 25 de junio de 1628.

${ }^{56}$ Descripción breve del Monasterio de San Lorenzo el Real del Escoria. Única maravilla del Mundo. Fábrica del Prudentísimo Rey Philipo Segundo. Ahora nuevamente coronado por el Catholico Rey Philipo Quarto el Grande. Con la Magestuosa Obra de la capilla insigne del Pantheon y traslación a ella de los Cuerpos Reales. Dedicada a quien tan ilustremente la corona por el P.F. Francisco de los Santos. Lector de Escritura Sagrada en el colegio Real de la misma casa. Madrid, 1657 Ed. facsímil, Madrid, 1984. La obra se compone de dos libros, más un apartado titulado Traslación de los cuerpos reales. En el primer libro se sigue muy de cerca el texto de Fray José de Sigüenza En el libro segundo, Santos dedica siete discursos al Panteón y otros cinco más a la oración fúnebre donde se narran las ceremonias de traslado de los cuerpos reales. En los grabados intervino Pedro de Villafranca, por entonces grabador real. Sobre esta obra impresa se aportan referencias en los trabajos de C. MONEDERO CARRILlO DE ALBORNOZ, " La figura de fray Francisco de los Santos", Anales del Instituto de Estudios Madrileños, V, 1970.pp. 203-263; A. Bustamante, “El Panteón de El Escorial. Papeletas.." pp. 214-215. gráfico sobre el recinto funerario, dispuestos para servir de fuente de inspiración para ejemplos análogos.

La estimada apreciación que el espacio fúnebre escurialense alcanzó en los años centrales de esta centuria, unido a los ideales artísticos del barroco hispano pudieron ser las causas que determinaron al capellán de la corte, José de Garandillas Velasco a proponer, de nuevo, la reforma de la Capilla de los Reyes de la colegiata leonesa, aprovechando la facultad real por la que, en calidad de visitador de dicho convento leonés, se le otorgaba poder para mejorar el funcionamiento y dependencias de centro religioso ${ }^{57}$.

En diversos escritos remitidos al rey Carlos II, fechados el 29 de mayo, 26 de junio y 14 de julio de 1692, el visitador manifestaba, de forma insistente, la conveniencia de trasladar los cuerpos reales desde el angosto panteón románico isidoriano a otro espacio o capilla del convento, donde pudieran disponerse con mayor decoro y amplitud $^{58}$. Justificaba su proyecto en función de la obligada decencia en que deben guardarse cenizas y huesos tan estimables, aunque, sin duda, sus afanes pretendían la realización de un nuevo panteón real acorde con los esquemas estéticos y artísticos del barroco.

${ }^{57}$ La noticia de este nuevo proyecto de reforma fue dada a conocer por, J. J. MARTíN GONZÁLEZ, "El Panteón Real de San Isidoro. Dos proyectos fracasados..."p. 160. Por nuestra parte tenemos constancia documental de este amplio y complejo proyecto en los informes y memoriales conservados en AGS, Patronato eclesiástico, leg. 277, fondo al que no referiremos en los párrafos siguientes.

58 AGS, Patronato eclesiástico, leg. 277. La valoración del panteón real medieval por parte del visitador Garandillas es bastante negativa, ya que considera el espacio corto e indecente, lo cual no permite la óptima celebración de misas y responsos en honor de los reyes, ni tampoco facilita la disposición adecuada de los sepulcros, que además, a su juicio, son "toscos, desproporcionados y desiguales". 
Ante los recelos que tal empeño había provocado en los círculos eclesiásticos locales y entre las autoridades leonesas, José de Garandillas remite al rey un memorial y un detallado informe del proyecto donde expone las razones de la nueva obra $^{59}$ (Figs. no 7-9). Por ellos sabemos que la idea era transformar el recinto de la hasta entonces librería conventual, (levantada en el siglo XVI por Juan de Badajoz, el Mozo), en nuevo panteón de reyes. Para ello, previamente, dice el informe del visitador, sería necesario suprimir el suelo que dividía la estancia en dos alturas y dejar un espacio único, de 45 pies de altura hasta la cornisa, más la bóveda, es decir, unos 60 pies de alto, por 68 pies de largo y 30 de ancho, con lo que resultaba un amplio conjunto, superior a la capilla mayor de la iglesia. La obra de remodelación y adaptación de la librería renacentista no estaba exenta de riesgo, sobre todo en lo referente a la supresión del suelo que la dividía en dos pisos, el superior dedicado hasta entonces a librería, propiamente dicha, y el inferior, al parecer, a cochera con acceso desde el exterior del templo, con cuyos muros de poniente comunicaba. En su informe pericial el maestro arquitecto de Benavente y Zamora, Antonio Carassa, nombrado por Garandillas, afirmaba que la operación no implicaba demasiado peligro para la fábrica, ya que contaba con buenos contrafuertes $\mathrm{y}$, sobre todo, porque el mencionado suelo daba la impresión de ser algo añadido con posterioridad a la primitiva construcción de la librería, con lo que el espacio resultante sería el original del siglo $\mathrm{XVI}^{60}$.

\footnotetext{
${ }^{59}$ Ibídem, las fechas de estos escritos son las del 26 de junio y 14 de julio de 1692 .

${ }^{60}$ Ibídem, Informe del maestro arquitecto Antonio Carassa, fechado en 26 de junio de 1692. En él el arquitecto dice tener unos sesenta años de edad. El texto dice: ...y que por fuera está fortalecida con muchos estribos de piedra labrada con sus frmes y remates de capiteles, y que en quitar su suelo en que está dicha librería, por que es de
}

La elección de este lugar se justificaba además por diversos motivos, en primer lugar, la elevada valoración artística de la librería, cuya amplitud espacial y bóvedas profusamente ornamentadas estaban más próximas a la estética del barroco que el antiguo panteón románico. De hecho Garandillas considera a la librería una pieza de muy extraordinaria arte y primor, siendo antiguo sobre todo un cielo matizado de oro, colores, figuras, muchas vidrieras muy crecidas, llegando a afirmar, que excede en primores a la capilla mayor $^{61}$, consideraciones que contrastan con la negativa calificación que paralelamente hace del panteón medieval. El aprecio por la librería se repite en el maestro arquitecto encargado de supervisar la obra, Antonio de Carasa, cuando escribe:

su cielo [es] de dos capillas de crucería, con media naranxa en medio obalada, adornada, assi las capillas, como la media naranxa, de muchas $y$ diefrentes labores y capiteles pendientes, de rara y extraordinaria fábrica y hermosura y en la pichinas del ovalo quatro figuras de prophetas de muy luzida escultura y assi mesmo quatro calaveras en quadro de dicho ovalo y otras insisnias fúnebres, y por toda la capilla muchas imágenes de bulto de ángeles, con sus tarxetas, de suerte que todo la compone muy hermosa de calidad, y es de singular fábrica ${ }^{62}$.

Una valoración positiva que también se deja ver en los dibujos del nuevo panteón proyectado en este período, en donde las bóvedas de crucería de la librería conventual renacentista aparecen representadas con todo tipo de detalles ornamentales para enfatizar su esplendor ( Fig. ㄲo 6 a 9)

\footnotetext{
-

ladrillo sin jargumento y da a entender se puso como de prestado, no ya riesgo ni peligro en su fábrica, y antes bien quedará muy segura y adornada grandemente la iglesia por el lugar a los fines y remates de ella...

${ }^{61}$ Ibídem. Carta de Garandillas de junio de 1692.

${ }^{62}$ Ibídem, Informe del maestro arquitecto Antonio Carassa fechado en 26 de junio de 1692.
} 
Junto a los motivos anteriores, la elección del nuevo panteón también era justificada por el visitador por el escaso coste, calculado en unos 1.000 ducados, cifra asumible por las rentas de la colegiata y, muy especialmente, por su fácil acceso desde el exterior e interior de la iglesia. Externamente el cuerpo inferior del recinto librario comunicaba con la plaza de San Isidoro a través de una puerta abierta desde antiguo en el muro de mediodía, hoy cegado. Por la parte interna lo hacía a través el muro de poniente que daba acceso a la nave lateral, permitiendo así el obligado culto a tales reliquias de forma más capaz y adecuada. Por otro lado, debido a la amplia configuración espacial y elevada altura del recinto, la disposición de los entierros ganaría en decoro sin necesidad de efectuar grandes obras, sino tan solo disponer las 38 nuevas urnas en dos cuerpos de nichos superpuestos, que alcanzarían hasta los 45 pies en que se sitúa la cornisa de arranque de la bóveda. Es en este detalle donde los ecos del Escorial vuelven a hacerse más evidentes. Garandillas describe que los sepulcros se colocarán en los tres lados del rectángulo (dejando libre el del altar) con sus labores de arcos, pirámides y rematados en escudos bastantemente creçidos con las armas reales, cada urna tendrá cinco pies de largo por tres de ancho, labrándose en piedra con sus labores y tarjetas en donde se pongan los rótulos de cada cuerpo real para conservar la memoria de estos señores reyes. Desea que el conjunto sea uniforme y proporcionado para evitar lo que sucedía en el antiguo panteón, cuyos sepulcros calificaba de toscos, desiguales, unos más altos que otros, lo que hacía a la capilla con poca hermosura, por sus desigualdades.

Como ya publicó J. J. Martín González, las opciones de Gandarillas fueron aceptadas inicialmente por el patronato real, y por orden del visitador, en 1692 se iniciaron las obras, encargando sendos proyectos a los arquitectos Antonio Carassa ${ }^{63} \mathrm{y}$ Manuel Conde Martínez ${ }^{64}$. Fue el de este último el que tuvo mayor aceptación y el que sirvió como referente para dar comienzo a las obras de reestructuración de la librería, con el consiguiente traslado y reforma del viejo recinto funerario y su firma figura en los dibujos conservados hoy en el Archivo General de Simancas ${ }^{65}$ (Figs. nº 6,7 y 8). La elección de las trazas de Conde Martínez pone de relieve la voluntad de adaptar la estructura a los esquemas plenamente barrocos, conforme a la estética imperante en la época y siguiendo unas pautas de actuación bastante frecuentes en los ámbitos religiosos hispanos. Sin ir más lejos, la propia catedral leonesa también había emprendido actuaciones a favor de la transformación de algunos partes de templo de Regla en elementos plenamente barrocos, siendo Manuel Conde Martínez el maestro de obras que desde 1694 se encargará de esa transformación ${ }^{66}$.

\footnotetext{
${ }^{63}$ Martín González le denomina Antonio del Solar, no Antonio Carassa, como leemos en el documento.

${ }^{64}$ J. J. MARTín GONZÁLEZ, "El Panteón Real de San Isidoro. Dos proyectos fracasados..."p. 162.

65 AGS, Patronato Eclesiástico, leg. 277 y M.P. y D. II-20, VI, 41

${ }^{66}$ Manuel Conde Martínez fue maestro de obras de la catedral de León desde 1694 hasta principios del siglo XVIII. Para este templo realizó los proyectos de la linterna de la cúpula levantada por Juan de Naveda y los remates para la reconstrucción del hastial sur. Sobre su personalidad se aportan referencia biográficas en los trabajos de: D. DE LOS Ríos, La catedral de León, León, 1895, t. II, pp. 24-25; P. NAVASCUÉs PALACIO, "Arquitectura del siglo XIX. Las fachadas de la catedral de León" Estudios Pro Arte, no 9, Barcelona, 1977, pp. 53: J. RIVERA BLANCO, Historia de las restauraciones de la catedral de León, Valladolid, 1993, pp. 122124; I. GONZÁLEZ-VARAS IBÁÑEZ, La catedral de León. Historia y restauración (1859-1901), León, 1993, pp. 79 y 333; M. D. CAMPOS SÁNCHEZ-BORDONA "Las transformaciones del renacimiento y el esplendor barroco" en Una historia arquitectónica de la catedral de León, dir. M. Valdés, León, 1994, pp. 203-214; E. MORÁIS VALLEJO, Aportación al barroco en la provincia de León. Arquitectura religiosa, León, 2000, p. 307. En ninguno de los estudios
} 
Ante tal evidencia surgen de nuevo las protestas del entonces abad de la colegiata, don Baltasar de Prado, quien remite al rey los correspondientes memoriales a través de los cuales intentará detener los afanes reformistas y barrocos que abogaban por el traslado del panteón real ${ }^{67}$. En primer lugar, trata de desacreditar al promotor de la obra, el visitador José de Garandillas, a quien acusa de todo tipo de excesos, mala conducta, declarada enemistad con la persona del abad e intento de derrochar las rentas de la colegiata, como lo demuestra la duración de su visita al convento isidoriano, que se prolonga ya por tiempo de nueve meses, sin que tal dilación fuera necesaria nada más que para su personal convenien$\mathrm{cia}^{68}$.

El abad desaconsejaba el traslado y seguía considerando el panteón medieval como el lugar más adecuado para las funciones funerarias que históricamente había desempeñado. Esta valoración de recinto románico se hacía en una doble vertiente. Por un lado, desde el punto de vista artístico, procuraba señalar la importancia de las pinturas de la bóveda, adecuadas a la función que cumplía el espacio y hacía notar "los que entienden de arte y han mirado bien el Panteón lo reputan de estrecho, pero no indecente, por que la techumbre está bien pintada, pues semejantes fábricas sepulcrales no tienen

anteriores se hace referencia a la intervención de Conde Martínez en la reforma del panteón isidoriano. Tan solo figura en el artículo ya citado de J. J. MARTín GonZÁLEZ, "El Panteón Real de San Isidoro. Dos proyectos fracasados..." pp. 160-165.

${ }^{67}$ AGS, Patronato eclesiástico, leg. 277, El memorial lleva fecha de 21 de diciembre de 1692.

${ }^{68}$ El memorial de agravios y quejas respecto de la figura del visitador Garandillas es muy amplio y con graves acusaciones de todo tipo de delitos, desde falsedad de documentos, torturas, castigos de excomunión injustificados a los canónigos, hasta empleo del dinero de forma arbitraria, asistencia a espectáculos profanos, comedias y toros, vestido de religioso y una larga lista de faltas en las que la personalidad del visitador sale muy mal parada. claraboyas, ni otros primores alegres, sino fúnebres y melancólicos que exziten la piedad... De esa forma intentaba contradecir las razones estéticas y litúrgicas de la oscuridad, angostura y mala visualización, esgrimidas por Garandillas para justificar el cambio a la librería, a la que, sin embargo, el abad descalifica como obra de ladrillo y yeso, morisca. Por otro lado, Baltasar de Prado valoraba el viejo recinto funerario áulico aludiendo a su pleno sentido histórico, al ser el lugar elegido por los propios reyes, quienes, conforme a la antigua tradición y de acuerdo a su modestia, dispusieron que sus cenizas no reposasen en el interior, sino a poniente de la iglesia, frente al altar mayor y lo más cerca que pudiesen gozar de la presencia de Dios Sacramentado, por lo que, desde entonces, señala el abad, comunicaron el panteón con el templo a través de una reja de hierro acaracolada. Tal apertura determinaba suficiente comunicación y buena visualización para permitir la celebración y audición del culto divino, contradiciendo así alguna de las razones interpuestas para el traslado por el visitador.

Terminaba don Baltasar de Prado exponiendo otras razones de peso para evitar el cambio, como eran los problemas de conservación y deterioro que podrían derivarse del traslado de los féretros y su colocación en urnas más reducidas, el desacato que todo ello implicaría a los cuerpos reales, alguno de los cuales se suponía incorrupto, como el de San Fernando. Añadía que las trazas para el nuevo panteón se habían realizado por maestros de la conveniencia del visitador, sin que el lugar elegido fuera adecuado, ni tampoco proporcionado a la función que se iba a destinar, amén de los gastos para la colegiata, $\mathrm{y}$ hasta advertía, en tono amenazador, de la ruptura con la vieja tradición del pueblo leonés que consideraba a la capilla de Santa Catalina lugar donde se apareció la Virgen y como tal espacio protegido por Ella. Por todo ello suplicaba se solicitaran informes a 
la Ciudad, al obispo y a personas residentes en la Corte que conociesen el caso, como eran don Juan de Feloaga y don Francisco Ronquillo, antiguos corregidores de León, por entonces en Madrid. Pero también requería el parecer de teólogos, juristas y arquitectos, ya que la cuestión planteaba diversos resortes que él se encargaba de resaltar en su informe y memorial, con ánimo de impedir que la obra fuera adelante.

Las alegaciones de don Baltasar de Prado tuvieron más apoyo que las de Gandarillas y en enero de 1693 la Cámara de Castilla determinó la paralización de las obras que ya habían dado comienzo bajo la autorización del visitador y conforme a los proyectos diseñados por Manuel Conde ${ }^{69}$.

Una vez más se frustraban los planes de reforma del antiguo panteón isidoriano. En esta ocasión la intencionalidad era transformar el recinto medieval, o en su defecto la librería de la colegiata, en un espacio fúnebre barroco, con la mirada puesta de nuevo en El Escorial. Como en este ejemplo, se pretendía convertir el panteón leonés en una pieza autónoma, de elevada magnificencia, buena luz y suntuosa ornamentación. Sin llegar al empleo de los ricos materiales utilizados en San Lorenzo, ni tampoco seguir de cerca su configuración arquitectónica centralizada, debido a la diferencia espacial entre ambos conjuntos, la obra leonesa diseñada por Manuel Conde Martínez es menos clasicista y monumental, aunque la colocación de las urnas guarda alguna analogía al disponerlas adosadas a la pared, sobre un basamento o zócalo, en dos cuerpos de nichos superpuestos. Como se contempla en el dibujo, (Fig. no 9) el conjunto estaba conformado por arcos rebajados sustentados, en la parte inferior, por

\footnotetext{
${ }^{69}$ AGS, Patronato eclesiástico, leg. 277. La Cámara determina la paralización y supresión del proyecto el 19 de enero de 1623.
}

pedestales ornados con hornacinas aveneradas y motivos vegetales, mientras que en la parte superior se recurre a pilastras cuyo frente se adorna con sartas de frutas y motivos vegetales. En el interior de los arcos se abren los nichos que cobijan las urnas reales, asentadas sobre pequeños soportes en forma de garra y cabezas de león, en clara alusión a la ascendencia histórica. El conjunto parietal se remata con las armas de Carlos II sostenidas por sendos leones rampantes y coronados, a los que acompañan dos esculturas alegóricas, emblemas del reino leonés.

Junto con los detalles artísticos y ornamentales del panteón, las trazas de Manuel Conde Martínez nos aportan otras importantes particularidades sobre la fábrica de la real colegiata. Entre ellas nos ha legado los dibujos de la planta de la librería y del viejo panteón románico, tal y como se encontraban en el siglo XVII. Es evidente que en su proyecto, el arquitecto, se detiene de manera más pormenorizada y concede mayor importancia al recinto librario y a su compleja cubierta, plenamente ornamenta$\mathrm{da}$, que al espacio funerario medieval, fruto, como ya hemos señalado, de un gusto y estética que busca en el recargamiento decorativo la fórmula para conferir al nuevo recinto áulico el ornato, la suntuosidad aparente y la magnificencia, tan deseadas en el barroco.

Igualmente, son dignas de reseñar las imágenes relacionadas con el viejo panteón real, donde destaca la colocación de los sepulcros, dispuestos de manera algo amontonada en el espacio central de la capilla (a excepción del de don Fernando y doña Leonor, sito en el muro oeste), ubicación que desde el siglo XVI venía siendo uno de los puntos de fricción a favor de la construcción de un recinto nuevo, más amplio y decoroso. En este mismo dibujo podemos observar cómo la comunicación del panteón con la iglesia colegial se efectuaba 
por entonces a través de una única puerta que se abría a la nave mayor. De hecho la otra puerta, abierta en la nave lateral, daba acceso al piso inferior de la librería, señalándose en el dibujo la intencionalidad de cerrarla por la falta de función, ya que el espacio correspondiente al cuerpo bajo de la librería tenía acceso directo con el exterior a través de una puerta, sita en el muro de mediodía, la cual, al parecer y según reza la leyenda del plano de Manuel Conde, abierta desde antiguo para comunicarlo con la plaza (Figs. no 7 y 8$)^{70}$.

El tercero de los diseños del proyecto barroco nos ofrece una imagen general del conjunto de la iglesia, panteón y librería colegial en el siglo XVII, pero con datos de interés para el mejor conocimiento de la fábrica medieval, ya que algunas de sus dependencias permanecían sin alterar y conservaban su primitiva configuración. Se han señalado las puertas que daban acceso al claustro, la capilla bautismal, la de San Pedro, así como ciertas mediadas del recinto $^{71}$. No obstante, la voluntad del arquitecto era enfatizar el espacio en el que se había proyectado trasladar el panteón, y hacerlo atractivo a los ojos de los posibles examinadores y del propio rey, para que determinaran a favor de una obra que él colmaba de magnificencia y esplendor. A pesar de estos intentos, la obra no llegó a buen término y fue rechaza por el abad y capitulares leoneses.

Terminaba de esta manera el último de los seculares intentos de alterar y modificar el antiguo panteón románico de los reyes de León, que durante la Edad Moder-

\footnotetext{
${ }^{70} \mathrm{El}$ dato es de interés y viene a recordar que la librería se construyó en el siglo XVI sobre parte de lo que posiblemente fueron las antiguas dependencias de los palacios reales que se levantaron en la Edad Media anejos al edificio religioso., delante de los cuales se abrió plaza pública.

${ }^{71}$ De hecho en el dibujo aparecen las referencias a la escala que se inserta en él.
}

na se vio amenazado por las nuevas formalidades litúrgicas contrarreformistas, por los deseos de exaltación dinástica de la Monarquía hispánica de los Austria, por las propuestas estéticas del renacimiento o del barroco, y por la escasa valoración que tuvo el arte medieval durante la Modernidad. Todavía en el siglo XVIII, la angostura del recinto era una de las críticas aludidas por los visitadores, tal y como refiere José Antonio de Goiri en 1761 en su visita al panteón y entierro de los señores reyes, haciendo notar que a su juicio:

...en dicho panteón, por no haber disposición cómoda para altar, por estar todo él lleno de sepulcros, se abrió antiguamente un arco pequeño y debajo de él ai un altar muy reducido en que apenas cabe un ara proporcionada, el misal y lo demás necesario para celebrar el Santo Sacrificio con decencia... y habiéndose reconocido en esta visita que no ai en dicho panteón sitio alguno en donde colocar altar con decencia, quedó en tomar la providencia de que se ponga altar portátil enfrente de dicho panteón, donde mejor convenga... ${ }^{72}$

\footnotetext{
72 ASIL, I-d, caja 73, nº 7. En la relación de esta visita de Goiri se insertan los epitafios y leyendas identificativas de cada uno de los sepulcros del panteón real, que suman un total de 23 en esta ocasión..
} 


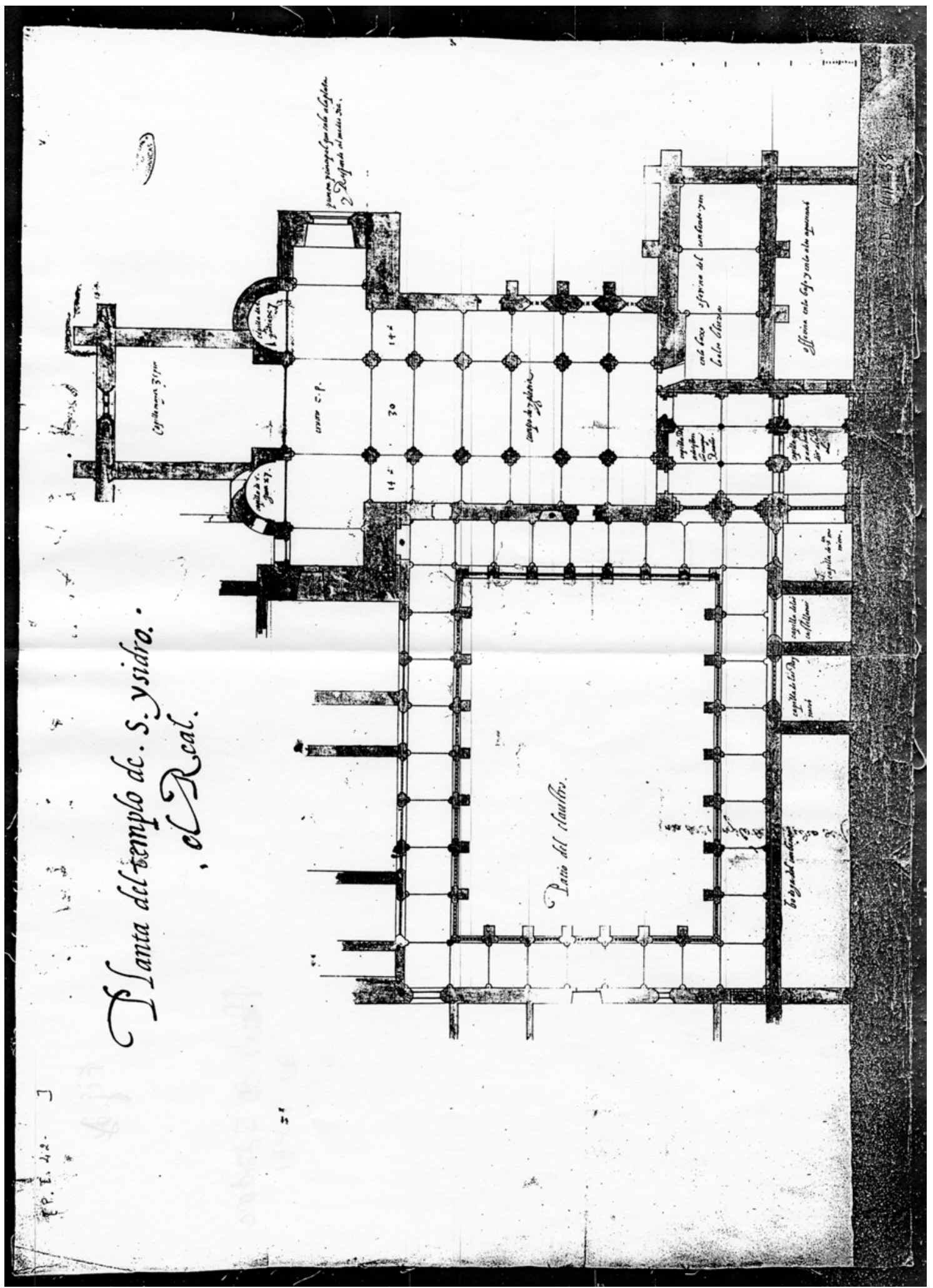

- Fig. 1. Dibujo de la planta de la iglesia y del Panteón de San Isidoro de León en el siglo XVI realizada por Juan del Ribero y Baltasar Gutiérrez (Ministerio de Cultura. AGS. Patronato eclesiástico, leg. 42, MPD. VIII-38) 


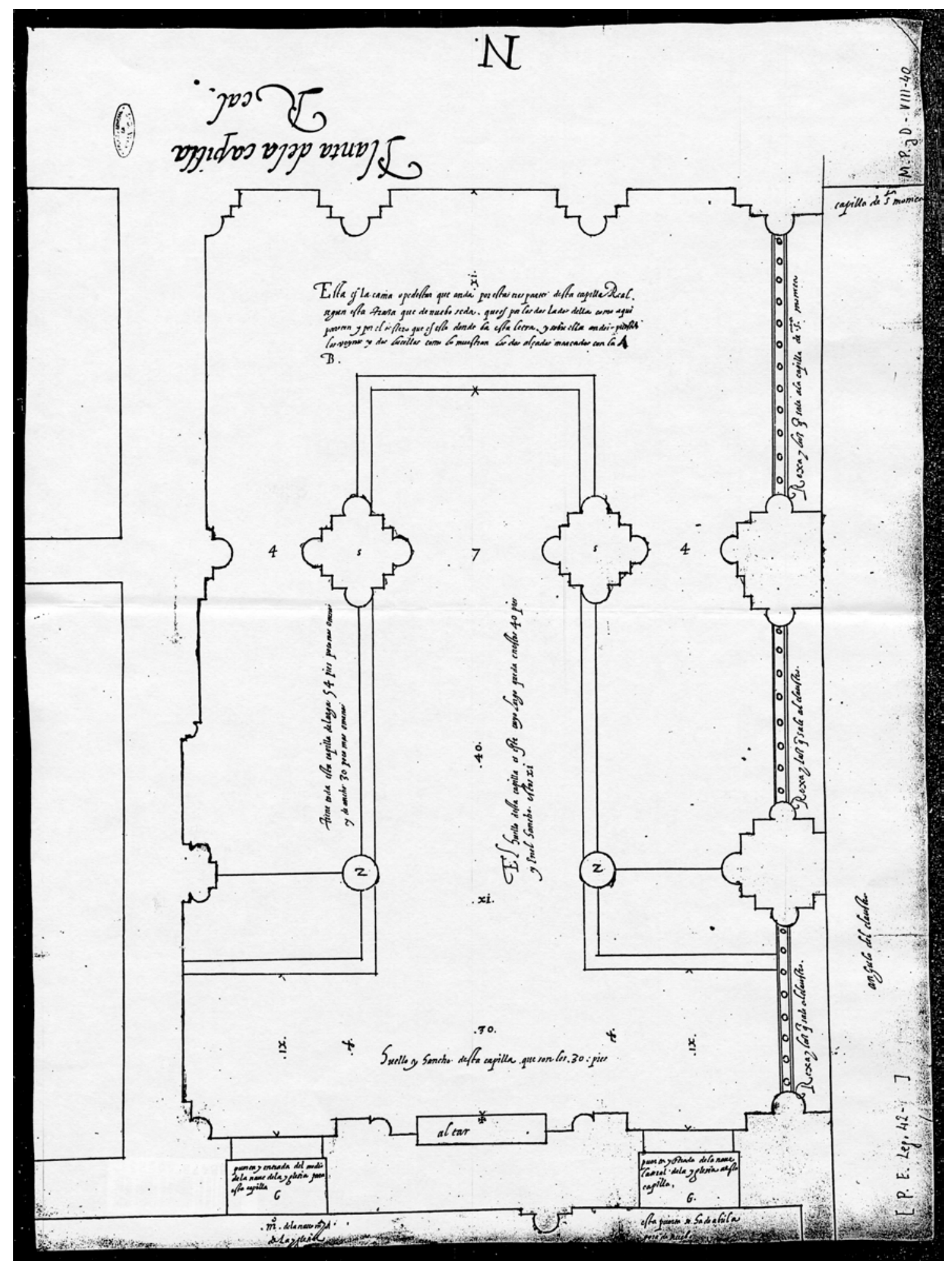

- Fig. 2. Dibujo de la planta del Panteón real de San Isidoro de León con la anexión de la capilla de Santa Catalina realizada por Juan del Ribero y Baltasar Gutiérrez en 1590 (Ministerio de Cultura. AGS. Patronato eclesiástico, leg. 42, MPD. VIII-40) 


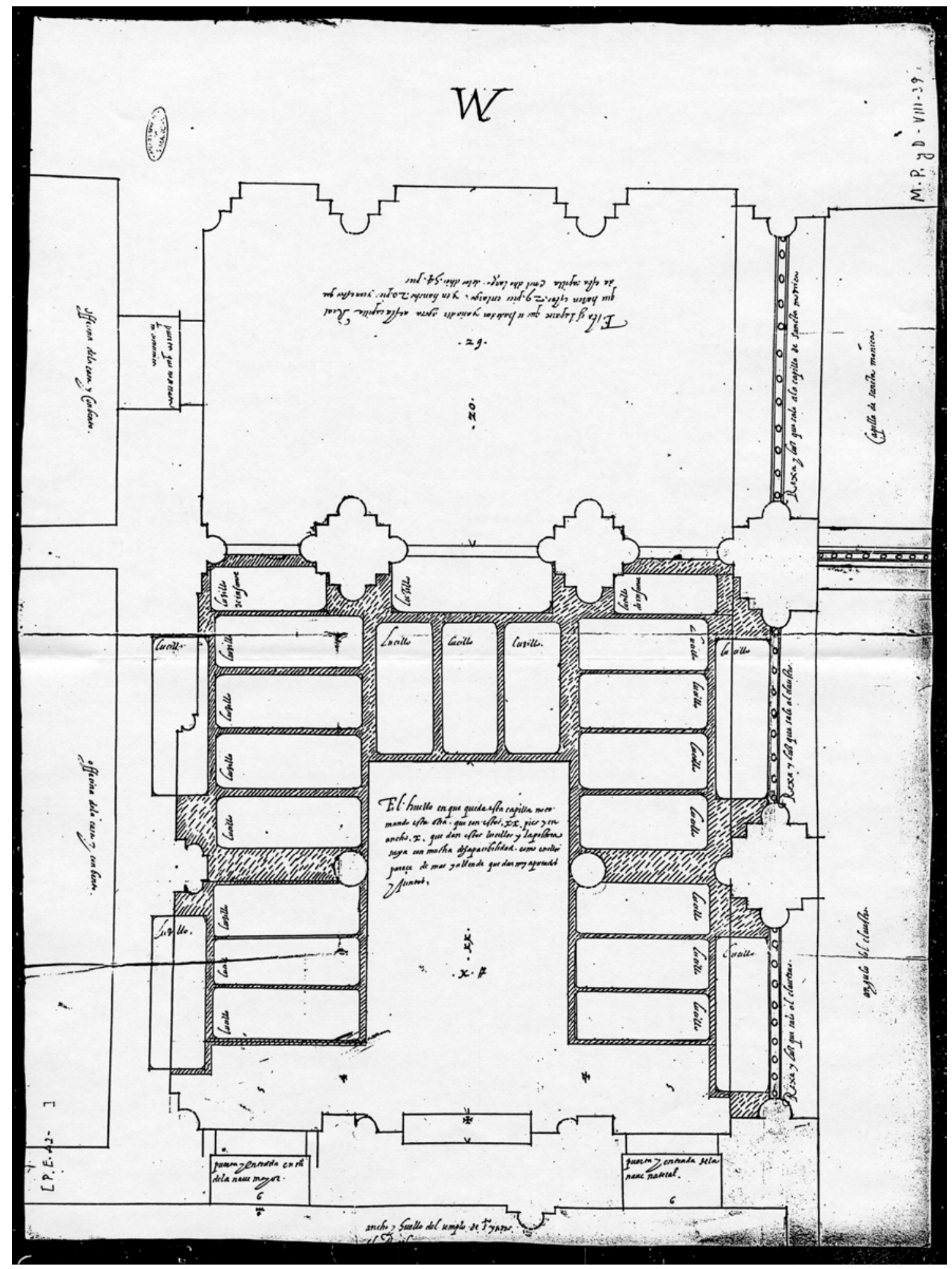

- Fig. 3. Dibujo de la planta del Panteón Real de San Isidoro de León con la disposición de los sepulcros en su interior realizada por Juan del Ribero y Baltasar Gutiérrez en 1590 (Ministerio de Cultura. AGS. Patronato eclesiástico, leg. 42, MPD. VIII-39) 


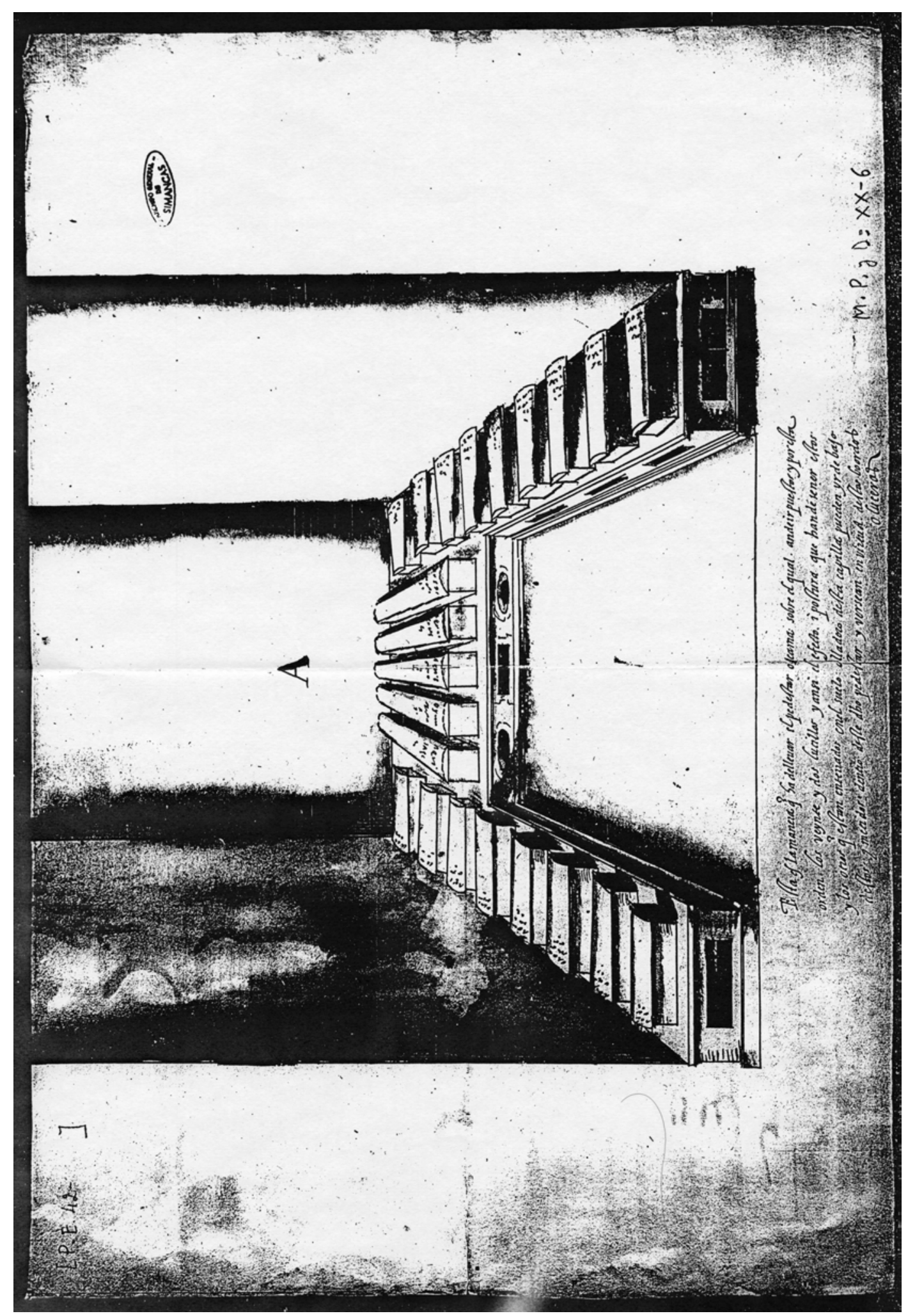

- Fig. 4. Modelos de cenotafios y disposición de los sepulcros dentro del Panteón Real de San Isidoro de León. Dibujo realizado por Juan del Ribero y Baltasar Gutiérrez (Ministerio de Cultura. AGS. Patronato eclesiástico, leg. 42, MPD. VV-6) 


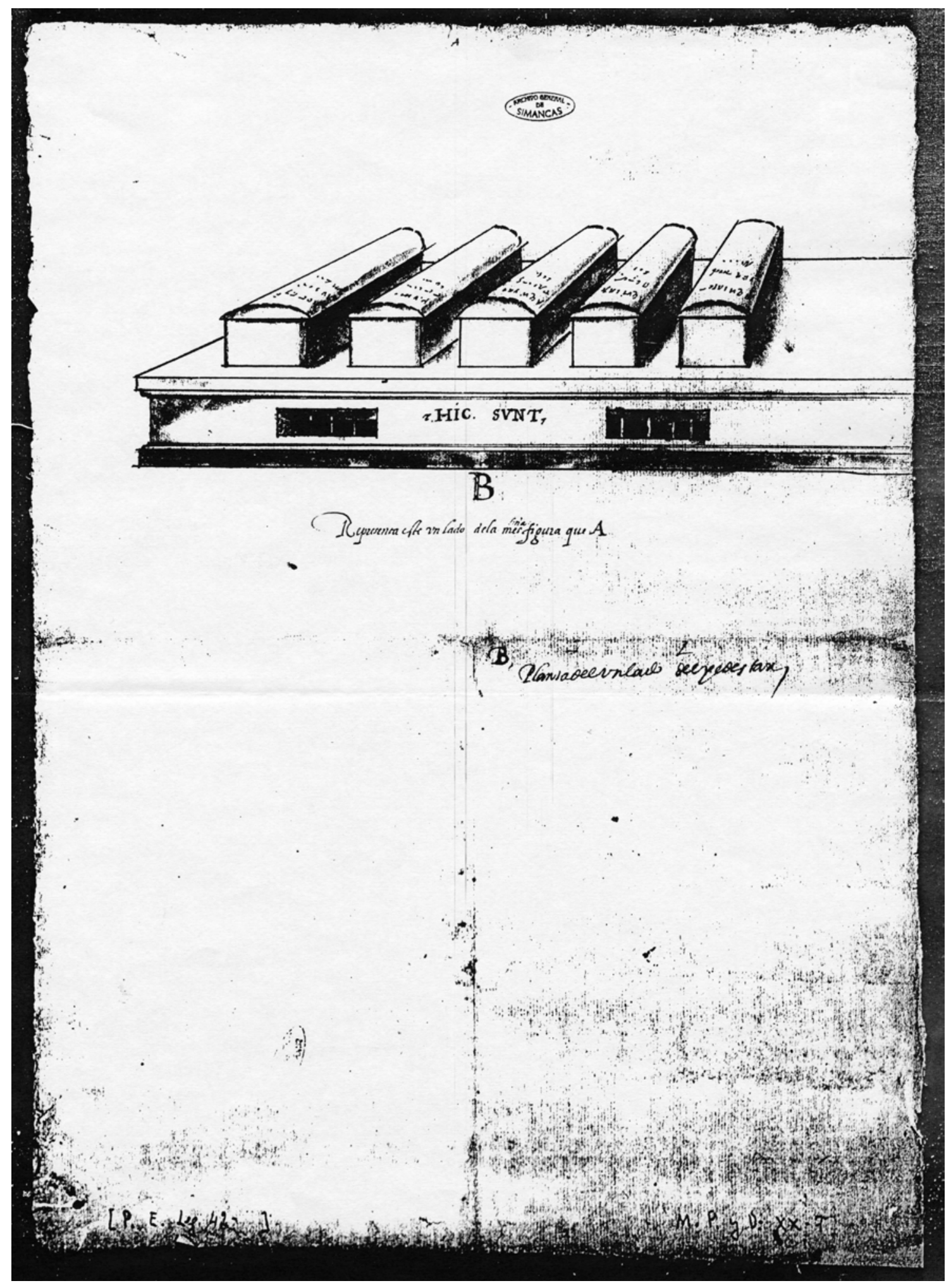

- Fig. 5. Modelos de sepulcros para el panteón de San Isidoro según dibujos del proyecto de reforma en el siglo XVI (Ministerio de Cultura. AGS. Patronato eclesiástico, leg. 42, MPD. $\mathrm{XX}-7)$ 


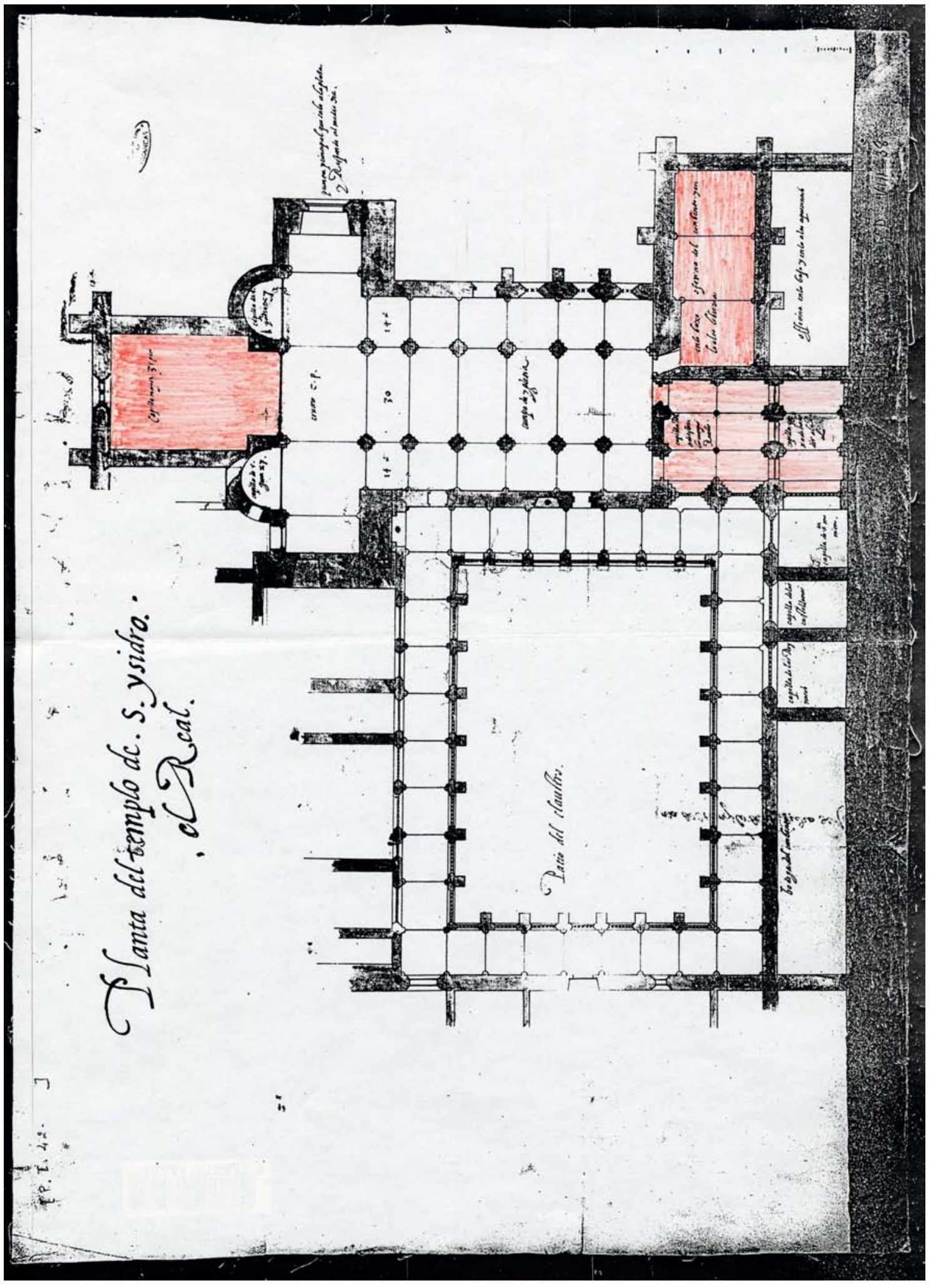

- Fig. 6. Esquema de la tres posibles ubicaciones que se eligieron en los siglos XVI y XVII para el traslado y nueva construcción del panteón de San Isidoro de León, señaladas por nosotros en color rojo sobre la planta dibujada en el proyecto de 1590 


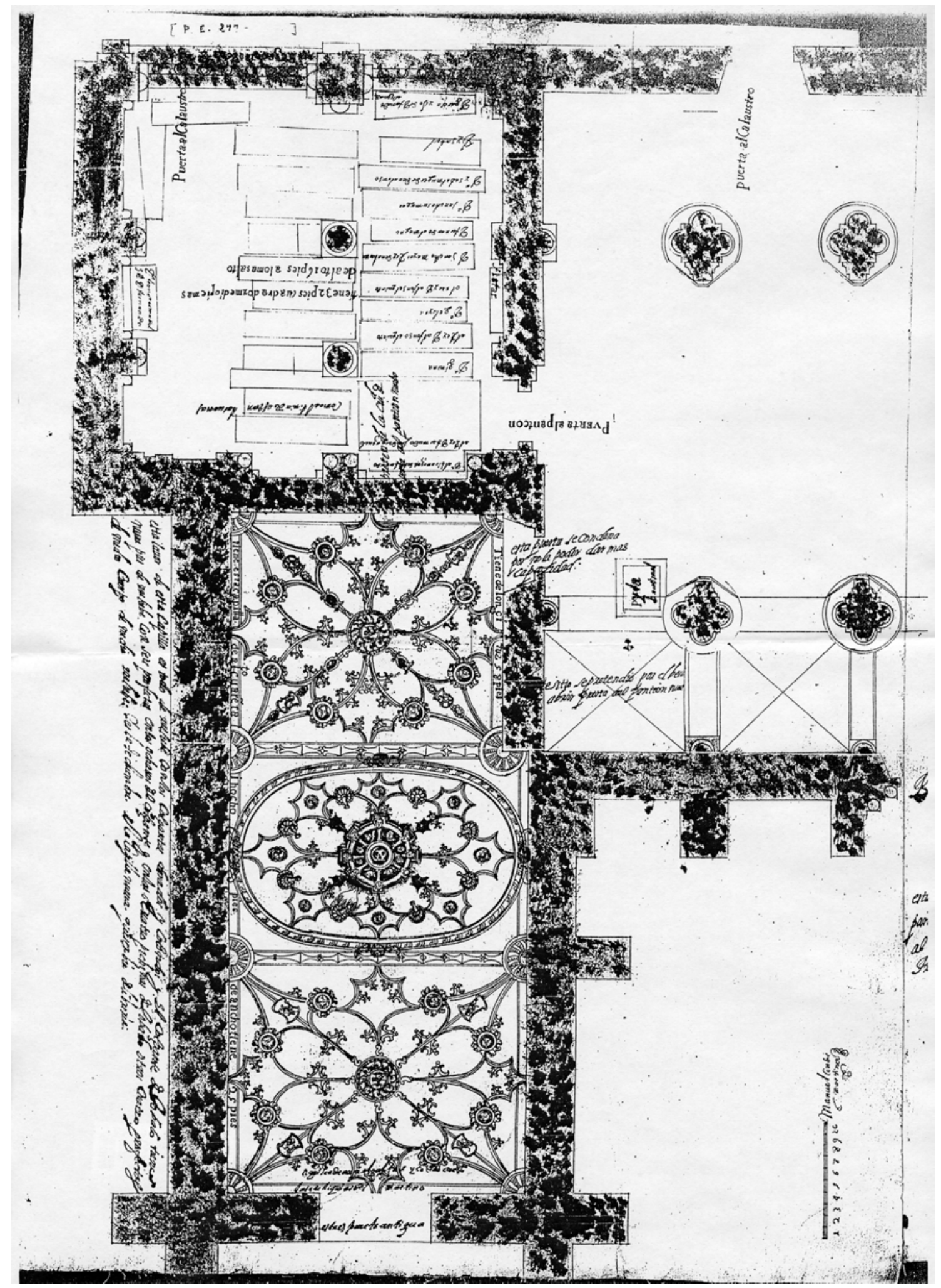

- Fig. 7. Planta del panteón, iglesia y librería colegiata de San Isidoro en 1692, realizada por Manuel Conde Martínez (Ministerio de Cultura. AGS. Patronato eclesiástico, 277, MPD. II,20) 


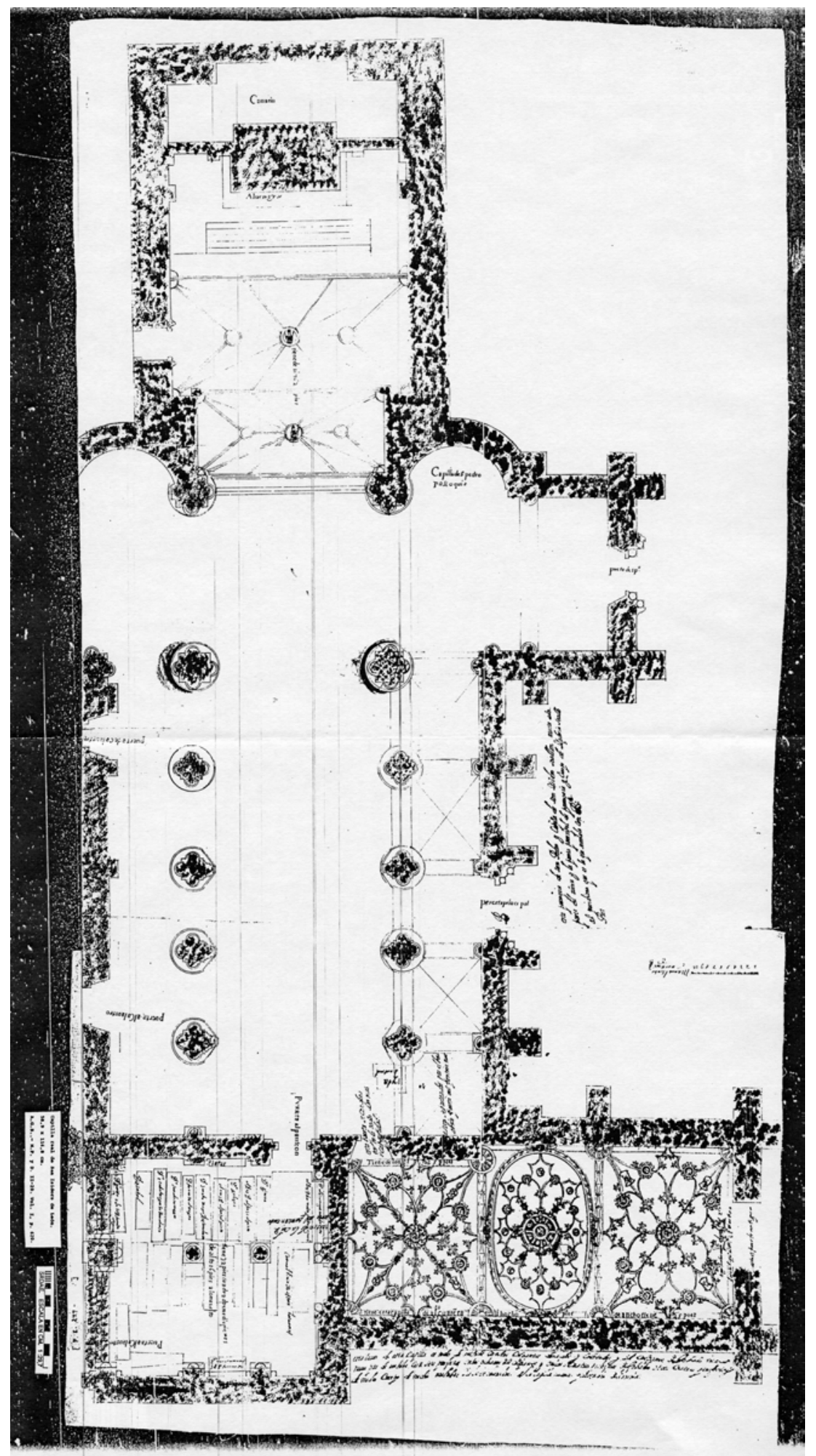

- Fig. 8. Detalle de la planta del panteón, iglesia y librería colegiata de San Isidoro en 1692, realizada por Manuel Conde Martínez (Ministerio de Cultura. AGS. Patronato eclesiástico, 277, MPD. II, 20) 


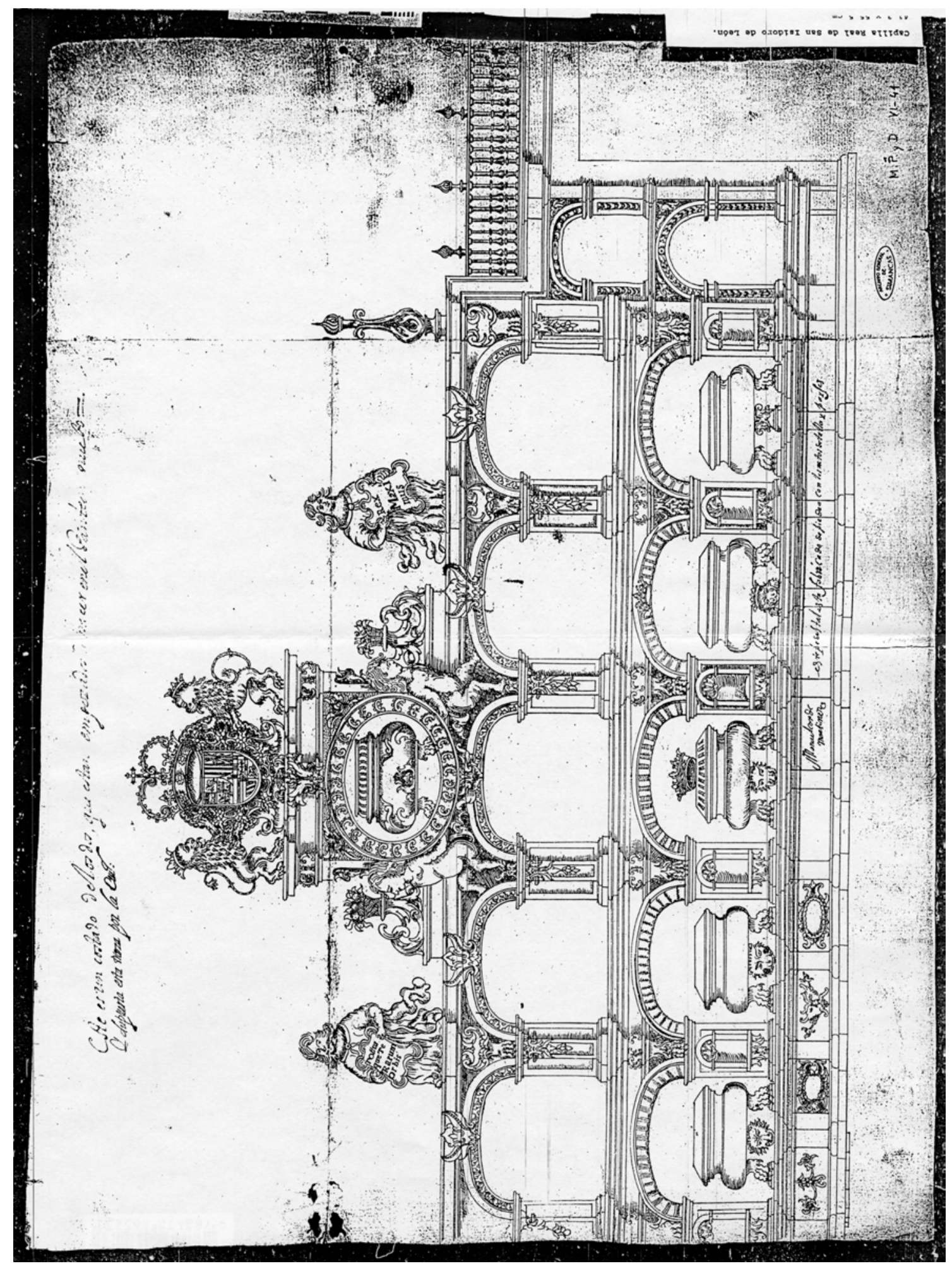

- Fig. 9. Dibujo con el alzado de las urnas y bichos del nuevo panteón real de San Isidoro en 1692, realizada por Manuel Conde Martínez (Ministerio de Cultura. AGS. Patronato eclesiástico, 277, MPD. VI-41) 